ARCHIWA - KanCELARIE - ZBIORY

NR 2 (4)/2011

\title{
MateriaŁy do BibliografiI ARCHIWISTYKI POLSKIEJ ZA ROK 2010
}

\section{Czasopisma}

„Archeion”, t. 110, 2007-2008, red. nacz. K. Stryjkowski, Warszawa 2010, wyd. Naczelna Dyrekcja Archiwów Państwowych, ss. 329, ilustr., sum., res., sod.

G. Ignaczak-Bandych, S. Radoń Projekt modernizacji infrastruktury archiwów państwowych, s. 9-20.

W dziale „Artykuły i Materiały”: W. Stępniak, Archiwiści polscy i rosyjscy na pierwszych stronach gazet. Problemy dokumentowania ludobójstwa katyńskiego, s. 21-33; W. K. Roman, $O$ naturze $i$ definicji informacji archiwalnej, s. 34-45; K. Maciejko, Wdrażanie normatywy archiwalnej Kodeksu Prawa Kanonicznego w polskich archiwach kościelnych na przyktadzie archiwów diecezjalnych $w$ Olsztynie, Pelplinie i Toruniu - próba oceny, s. 46-52; M. Szczepaniak, Wartość źródtowa kronik szkolnych na podstawie materiatów z terenu powiatu gnieźnieńskiego, s. 53-68; A. Prokopiuk-Lewandowska, Ewakuacja Archiwum Ministerstwa Spraw Zagranicznych we wrześniu 1939 r., s. 69-82; R. Stelmach, Straty w dokumentach i aktach dawnych depozytów w świetle inwentarzy i repertoriów archiwalnych Archiwum Państwowego we Wroctawiu, s. 83-102; S. Ziółek, Kancelaria i archiwum Sejmu Polskiego na emigracji w latach 1832-1848, s. 103-117; J. Gaul, Polonika w archiwach austriackich, s. 118-144; U. Kowalczyk, Archiwum Polskiej Misji Katolickiej we Francji, s. 145-153.

W dziale recenzyjnym odnotowano następujące publikacje: Polscy jeńcy wojenni w niewoli sowieckiej w latach 1919-1922. Materiaty archiwalne, red. Z. Karpus, W. Rezmer, E. Rosowska, I. Kostiuszko, Warszawa 2009; F. Banat-Berger, L. Duplouy, C. Huc, L'archivage numérique à Long terme. Les début de la maturité? Manuel et guides pratiques, Paris 2009; M. van Balle- 
gooie, W. Duff, Instalment on „archival metadata”, 10 May 2006, http://www.dcc.ac.uk/resource/curation-manual/chapters/archival-metadata; Księga kamlarii maista Torunia z lat 1453-1495, wyd. K. Kopiński, K. Mikulski, J. Tandecki, Toruń 2007; W kręgu „teczek”. Z badań nad zasobem i funkcjami archiwum Instytutu Pamięci Narodowej, red. H. Bednarek, P. Perzyna, Toruń 2007; I. Mamczak-Gadkowska, Archiwa państwowe w II Rzeczypospolitej, Poznań 2006; S. Lehr, Ein fast Vergessener „Osteinsatz”. Deutsche Archivare im Generalgouvernement und im Reichskomissariat Ukraine, Düsseldorf 2007; Informator o zasobie archiwalnym Centralnego Archiwum Wojskowego, red. N. Bujniewicz, Warszawa 2008; Archiwum Zbigniewa Herberta. Inwentarz, oprac. Henryk Citko, Warszawa 2008; Baltic Connections: Archival Guide to theMaritime Relations of the Countries around the Baltic Sea (including the Netherlands) 1450-1800, vol. 1-3, ed. by L. Bes, E. Frankot, H. Brand, Leiden - Boston 2007; I. Štarha, Moravský zemský archiv v Brnè. 1839-1989. Dějiny ústavu, Brno 2003 i Moravský zemský archiv v Brně. Pamètni kniha k otevrení novostavby, red. K. Smutná, Brno 2007.

W „Przeglądzie czasopism” odnotowano: Comma, 2006, nr 1-2 ; Otieczestwiennyje Archiwy, roczniki 2004-2009; Der Archivar, r. 56, 2003; Nordisk Arkivnyt, z. 4, 2005; z. 1-4, 2006; nr jubileuszowy 2006; z. 1-4, 2007; nr 1-4, 2008; nr 1-4, 2009; Archivni Časopis, nr 1-4 (53), 2003; nr 54, 2004; Sbornik Archivnich Prací, nr 1-2, 2003; nr 1-2, 2004; Slovenská Archivistika, nr 1-2, 2003; nr 1-2, 2004.

W numerze opublikowano kronikę polskich archiwów w latach 2006-2007.

„Wspomnienia pośmiertne” poświęcono Franciszce Ramotowskiej (1922-2003), Annie Marciniak (1941-2007) i Marii Redeł (1947-2008).

\section{„Archiwa, Biblioteki i Muzea Kościelne”, t. 93, 2010, red. nacz. ks. W. Bie- lak, Lublin 2010, wyd. Wydawnictwo Katolickiego Uniwersytetu Lubel- skiego Jana Pawła II, s. 367, ilustr.}

„Studia i materiały” - tu m.in. ks. T. Bratkowski, Antyfonarz De tempore MS 1-4 z klasztoru benedyktynek w Staniątkach, s. 5-68; H. Mazur, Źródta do dziejów chęcińskich kościotów w zasobie Archiwum Państwowego w Kielcach, s. 119-152; D. Milewski, Pierwsze lata Archiwum Uniwersytetu Kardynata Stefana Wyszyńskiego w Warszawie - organizacja i funkcjonowanie, s. 153-160; s. E. Oszajca, Konserwacja rękopisu Mszat z Kraśnika (ok. 1400), inkunabutów i starodruków z Biblioteki Metropolitalnego Seminarium Duchownego w Lublinie, s. 163-174; K. R. Prokop, Polonica w katalogu obsady biskupstw tytularnych XVII-XIX w. z Archivo Segreto Vaticano (ASV), s. 175-210; K. R. Prokop, Polonica z drugiej potowy XVII oraz z XVIII i XIX w. w zbiorze "Iuramenta fidelitatis et professionis fidei in Archivo Segreto Vaticano" (ASV), s. 211-259; M. Rzepecka, Archiwum kapituty i parafii Opatów, s. 259-278.

„Recenzje i informacje” - m.in. A. Hamryszczak, Konferencja naukowa: Między teoria a praktyka. Ochrona zbiorów w matych bibliotekach i archiwach. Cieszyn 3-5 maja 2010, s. 319-324; Przegląd bibliograficzny, s. 355-364. 


\section{„Archiwariusz Zamojski”, przew. zesp. red. A. Kędziora, Zamość 2010, wyd. Archiwum Państwowe w Zamościu, ss. 142}

Publikowane są tu głównie artykuły oparte na zasobie Archiwum Państwowego w Zamościu i edycje źródeł z tegoż zasobu. Z zakresu archiwistyki: Wiadomości archiwalne (Nabytki, Witryna archiwalna, Wystawa "Jan Strzyżowski fotograf zamojski", Uczestniczymy w wystawach, Milion [wyświetleń Galerii], Jest taki plakat, Archiwalna ksiażka z obrazkami), s. 139-141.

\section{„Archiwista Polski”, nr 1 (57), 2010, red. nacz. E. Borodij, Bydgoszcz 2010, wyd. Stowarzyszenie Archiwistów Polskich, ss. 108, 2 nlb., sum.}

„Studia i materiały”: A. Krzemińska, Archiwalia pocysterskie - problem metodycznego opracowania, s. 7-26; A. Biedziak, Nadzór nad narastajacym zasobem archiwalnym we Wtoszech, s. 27-36; H. Staszewska, Uproszczone metody opracowania w archiwach państwowych-eksperyment metodyczny czy statystyczny?, s. 37-53.

„ABC archiwisty zakładowego”: M. Konstankiewicz, Wykaz ważniejszych aktów prawnych regulujących zasady postępowania z dokumentacją (część XXXV), s. 55-62.

W dziale recenzyjnym odnotowano pięć pozycji: Lietuva senuosiuose istorijos Šaltiniuose. Lietuvos Tükstantmečio programos parodos katalogas, Vilnius 2009; Informator o zasobie archiwalnym Instytutu Pamięci Narodowej (stan na dzień 31 grudnia 2008 r.), red. nauk. J. Bednarek, R. Leśkiewicz, Warszawa 2009; Nadwarciański Rocznik Historyczno-Archiwalny, nr 16, 2009; Rocznik Historyczno-Archiwalny, t. 20, 2007-2008; A. Pasternak, H. z Pasternaków Żelazkowa, Źródta historyczne w badaniach genealogicznych na przyktadzie opracowania historii wtasnej rodziny oraz mikroregionu jej zamieszkania. $Z$ dziejów powiatu starachowickiego, Starachowice 2009.

W „Kronice” sprawozdanie z działalności Sekcji Edukacji Archiwalnej SAP w latach 2007-2009, relacja z wystawy archiwalnej Leon Jeśmanowicz 1914-1989, matematyk, karykaturzysta i..., sprawozdanie z działalności toruńskiego oddziału SAP w latach 2008-2009, sprawozdanie z konferencji o kształceniu archiwistów i zarządców dokumentacji (Toruń, 2009), relacja z II Toruńskich Konfrontacji Archiwalnych obradujących pod hasłem Teoria archiwalna wczoraj-dziś - jutro, informacja o powołaniu Rady Archiwalnej na lata 2010-2013.

\section{„Archiwista Polski”, nr 2 (58), 2010, red. nacz. E. Borodij, Bydgoszcz 2010, wyd. Stowarzyszenie Archiwistów Polskich, ss. 110, 2 nlb., sum.}

„Studia i materiały”: T. Dziki, Stan zachowania źródet do dziejów ziemi dobrzyńskiej w XIX w. $Z$ warsztatu archiwisty i historyka, s. 7-17; A. Lewandowska, Charakterystyka archiwów na ziemi radomskiej i ich zasobów do 1920 r., s. 19-28; E. Markowska, Problem analizy i opisu 
treści jednostek archiwalnych w polskiej literaturze naukowej, s. 29-52; D. Matelski, Problemy z reprywatyzacja dziedzictwa kultury narodowej $w$ Europie Środkowo-Wschodniej $w$ latach 1989-2009, s. 53-68; B. Pazoła, Historia Zaktadów Górniczych „Lena” w Wilkowie w świetle zachowanych $w$ archiwum legnickim archiwaliów. Przyczynek do dziejów górnictwa miedziowego na Dolnym Ślasku, s. 69-76.

„ABC archiwisty zakładowego”: M. Konstankiewicz, Wykaz ważniejszych aktów prawnych regulujacych zasady postępowania z dokumentacja (część XXXVI), s. 77-84.

W dziale recenzyjnym odnotowano jedną pozycję: Z. Kiereś, S. Krupa, M. Węcki, $Z$ dziejów Temidy na Górnym Ślasku. Źródta do dziejów wymiaru sprawiedliwości od XV do XX wieku w zasobie Archiwum Państwowego w Katowicach, Katowice 2008.

W „Kronice” zamieszczono sprawozdanie z działalności legnickiego oddziału SAP w roku 2009, informację o jubileuszu 90-lecia Archiwum Państwowego w Piotrkowie Trybunalskim, sprawozdanie z konferencji „Czasopisma naukowe bibliotek, archiwów, muzeów, odbytej w Poznaniu w marcu 2010 roku, sprawozdanie z konferencji „Dokumentacja projektów finansowanych i współfinansowanych ze środków Unii Europejskiej” (Wrocław, październik 2009 r.).

Zamieszczono także nekrolog Stefana Krzysztofa Kuczyńskiego (1938-2010).

\section{„Archiwista Polski”, nr 3 (59), 2010, red. nacz. E. Borodij, Bydgoszcz 2010, wyd. Stowarzyszenie Archiwistów Polskich, ss. 110, 2 nlb., sum.}

„Studia i materiały”: J. Leśniewska, 20 lat samorzadu gminnego w Polsce - rzeczowe wykazy akt dla organów samorządu gminnego w obliczu zmieniajacych się kompetencji, s. 7-21; W. Chorążyczewski, A. Rosa, Zasada publiczności nowym paradygmatem archiwistyki?, s. 23-42; A. Baniecki, D. Bednarek, D. Żygadło, R. Forysiak-Wójciński, P. Gut, J. Leśniewska, M. Hlebionek, Materiaty do polskiego stownika sfragistycznego, s. 43-56; W. Klas, Archiwalia dotyczące Kościelskich herbu Ogończyk. Zarys problematyki, s. 57-66.

„Varia”: A. Krzemińska, Nowe czasopismo archiwalne, czyli jak potaczyć tradycję z nowoczesnościa oraz wejś́ z sukcesem na rynek wydawniczy, s. 67-75.

„ABC archiwisty zakładowego”: M. Konstankiewicz, Wykaz ważniejszych aktów prawnych regulujacych zasady postępowania z dokumentacja (częśc XXXVII), s. 77-86; A. Pasternak, Ochrona pracowników przed szkodliwymi czynnikami biologicznymi na przyktadzie Archiwum PKP we Wroctawiu, s. 87-93.

W dziale recenzyjnym odnotowano książkę T. Matuszaka, Archiwum Państwowe w Piotrkowie Trybunalskim w latach 1919-1951, Piotrków Trybunalski 2009.

W „Kronice” zamieszczono sprawozdanie z działalności poznańskiego oddziału SAP w roku 2009 i sprawozdanie z konferencji archiwistów krajów Grupy Wyszehradzkiej i Basenu Dunajskiego (Debreczyn, 2010). 


\section{„Archiwista Polski”, nr 4 (60), 2010, red. nacz. E. Borodij, Bydgoszcz 2010, wyd. Stowarzyszenie Archiwistów Polskich, ss. 108, 2 nlb., sum.}

„VI Powszechny Zjazd Archiwistów Polskich”: Protokót posiedzenia Komitetu Programowo-Naukowego VI Powszechnego Zjazdu Archiwistów Polskich z 18 listopada 2010 r., s. 9-12.

„Dokumenty Stowarzyszenia Archiwistów Polskich”: Model kompetencji zawodowych archiwistów i zarządców dokumentacji. Rekomendacja Zarządu Gtównego Stowarzyszenia Archiwistów Polskich uchwalona 4 listopada 2010 r., s. 13-19.

„Studia i materiały”: D. Magier, Archiwistyka wobec wyzwań świata cyfrowego, s. 21-28; T. Żuchowski, Akta związane z towiectwem w Archiwum Gospodarczym Wilanowskim, s. 29-35; D. Chyła, Dziatalność wystawiennicza archiwów w Polsce pótnocno-zachodniej w latach 2000-2010 z punktu widzenia muzealnictwa, s. 37-61; W. Klas, Archiwum Janiny z Ruszkowskich Kościelskiej w zasobie Archiwum Fundacji Kościelskich, s. 63-67.

„ABC archiwisty zakładowego”: M. Konstankiewicz, Wykaz ważniejszych aktów prawnych regulujących zasady postępowania z dokumentacja (częsí XXXVIII), s. 69-76.

W dziale recenzyjnym odnotowano: Zarządzanie dokumentacja w sektorze publicznym. Wzory i porady dotyczące obiegu dokumentów, red. E. Kujan, M. Sender, Warszawa 2009; Raport z dziatalności Naczelnej Dyrekcji Archiwów Państwowych i archiwów państwowych za lata 2008-2009, red. M. Berska, Warszawa 2010; Ksztatcenie archiwistów i zarządów dokumentacji. Model kompetencji zawodowych. Materiaty z konferencji Sekcji Edukacji Archiwalnej Stowarzyszenia Archiwistów Polskich, red. Wiesława Kwiatkowska, Poznań 2010.

W „Kronice” zamieszczono sprawozdanie z działalności wrocławskiego oddziału SAP w roku 2009 i sprawozdanie z I Międzynarodowego Seminarium Sfragistycznego (Kijów 2010).

\section{„Badania nad Dziejami Regionu Piotrkowskiego”, t. 8, 2009, red. nacz. A. Piasta, Piotrków Trybunalski 2010, wyd. Archiwum Państwowe w Piotr- kowie Trybunalskim, ss. 311}

Z zakresu archiwistyki: J. Łukasik, Źródta do dziatalności kulturalnej stronnictw politycznych i zwiazanych z nimi organizacji w Piotrkowie w aktach Starostwa Powiatowego Piotrkowskiego z lat 1918-1939, s. 78-91; T. Matuszak, Dzieje Piotrkowa w epoce jagiellońskiej w świetle spuścizny Michata Rawity-Witanowskiego z zasobu Archiwum Państwowego w Piotrkowie Trybunalskim, s. 92-102; A. Piasta, Towarzystwo Rolnicze w Królestwie Polskim (1858-1861) - zarys dziatalności i dzieje pozostatości aktowej, s. 103-118. 


\section{„Biuletyn Archiwum Polskiej Akademii Nauk”, nr 51, Warszawa 2010, wyd. Archiwum Polskiej Akademii Nauk, ss. 183, ilustr., sum.}

J. Arvaniti, Inwentarze archiwalne, s. 7-12 (autorka wyjaśnia dlaczego w tym numerze omówionych zostało sześć spuścizn polskich biologów oraz materiały Bronisława Edwarda Sydowa); T. Dobrzyński, K. Słodkowska, Materiaty Tytusa Chatubińskiego, s. 12-19; A. Chodkowska, J. Mizikowski, Materiaty Stanistawa Bilewicza, s. 20-29; J. Buda, M. Norkowski, H. Szymczyk, Materiaty Seweryna i Heleny Krzemieniowskich, s. 30-47; J. Stasiak, Materiaty Witolda Stawińskiego, s. 58-71; J. Arvaniti, Materiaty Bronistawa Edwarda Sydowa, s. 72-77; A. Klubiński, Źródta do dziejów nauczania w Instytucie Gospodarstwa Wiejskiego i Leśnictwa w Marymoncie w zasobie Archiwum Polskiej Akademii Nauk, s. 104-115; C. Beli, I. Gass, Korzenie geniuszu, s. 116-120; H. Krajewska, Dni Muzeum Polskiego w Rapperswilu, s. 121-127; R. Nikolajewna-Polianskaja, Rossijsko-polskije naucznyje swjazi i oblasti mongolowiedienija i tiurkologii w XX wiekie po matierialam Archiwa Polskoj Akademii Nauk, s. 128-142; Sprawozdanie z dziatalności Archiwum PAN w roku 2009, s. 143-159.

\section{„Biuletyn Informacyjny Archiwum Państwowego w Lublinie APLA”, R. 1, nr 3, grudzień 2010 [on-line]}

Trzeci już numer bezpłatnego „Biuletynu Informacyjnego Archiwum Państwowego w Lublinie APLA", który w wersji papierowej można za darmo uzyskać w pracowni naukowej archiwum lubelskiego, natomiast w wersji elektronicznej jest dostępny na stronie internetowej AP w Lublinie. Tematem przewodnim tego numeru jest digitalizacja zasobu archiwalnego. $\mathrm{Na}$ kilku stronach została przedstawiona lubelska pracownia digitalizacji i jej pracownicy oraz realizowany $\mathrm{w}$ tym archiwum proces digitalizacji materiałów archiwalnych, a także finansowany przez Ministra Kultury i Dziedzictwa Narodowego program „Zasoby cyfrowe”, dzięki któremu możliwa była rozbudowa infrastruktury digitalizacyjnej archiwum dokonana w 2010 r.

„Miscellanea Historico-Archivistica”, t. 15-16, 2008-2009, red. nauk. J. Krochmal, Warszawa 2010, wyd. DiG, ss. 238, 4 nlb., ilustr., sum.

Po kilku latach przerwy ukazał się kolejny tom pisma wydawanego od 1985 r. Wśrod publikowanych tu tekstów znajdują się m.in. materiały I Sympozjum „Publica in privatis”.

T. Zielińska, Archiwalia publiczne w zbiorach prywatnych, s. 5-13; M. Kulecki, Publiczne czy prywatne? Burzliwe losy spuścizny archiwalnej po królu Stanistawie Auguście, s. 15-21; L. Nowak, Rękopiśmienne zbiory proweniencji prywatnej w Bibliotece Jagiellońskiej, s. 23-24; K. Kossarzecki, Fortece i zamki radziwittowskie w XVII-XVIII wieku na podstawie zacho- 
wanych archiwaliów w Archiwum Warszawskim Radziwittów, s. 53-67; D. Lewandowska, Księga metrykalna parafii ormiańskiej w Ztoczowie (1685-1787) jako przyczynek do dziejów Ormian w Polsce, s. 145-152; P. Pietrzyk, Kolekcja autografów dr. Aleksandra Kahanowicza z Nowego Jorku w zbiorach Centralnego Archiwum Polonii w Orchard Lake, s. 153-168.

Na s. 181-216 znajdują się artykuły recenzyjne i recenzje. W dziale „Sprawozdania i komunikaty" pojawiły się m.in. teksty: A. Nowak, Polonika w archiwach obwodowych w Żytomierzu i Chmielnickim (Ukraina), s. 217-222; J. Krochmal, Przekazanie mikrofilmów z Centralnego Państwowego Archiwum Historycznego Ukrainy we Lwowie do Archiwum Gtównego Akt Dawnych $w$ Warszawie, s. 223-224. Poza tym fragment wspomnień Franciszki Ramotowskiej „W szponach NKWD”, s. 225-234.

„Nadwarciański Rocznik Historyczno-Archiwalny”, nr 17, red. nacz. D. Rymar, Gorzów Wielkopolski 2010, wyd. Towarzystwo Przyjaciół Archiwum i Pamiątek Przeszłości w Gorzowie Wielkopolskim i Archiwum Państwowe w Gorzowie Wielkopolskim, ss. 638, 4 nlb., ilustr.

Publikacja ma charakter historyczno-archiwalny i składają się na nią artykuły oraz teksty źródłowe dotyczące regionu gorzowskiego, ujęte w ramach następujących działów: „Rozprawy i przyczynki”, „Znalezione na archiwalnej półce”, „Dokumenty”, „Materiały do gorzowskiego słownika biograficznego”, „Polemiki, sprostowania, uzupełnienia, recenzje i omówienia”, „Wspomnienia”, „Komunikaty”, „Kronika Gorzowa”, „Nekrolog gorzowski”, „Książki o regionie”, „Materiały do bibliografii historii regionu”, „Nasi autorzy”. Szeroko rozumianą problematykę archiwalno-kancelaryjną poruszają trzy artykuły.

E. Syska, Jeszcze o najstarszych pieczęciach konwentu klasztoru cysterek w Petczycach, s. 63-66; M. Golemski, Arengi w XIII-wiecznych dyplomach biskupów lubuskich, s. 67-78; E. Rymar, Metryka i nazwy miejscowości dawnego powiatu gorzowskiego w granicach z lat 1945-1950, s. $179-252$.

„Płockie Zeszyty Archiwalne”, nr 1, Płock 2010, wyd. Archiwum Państwowe w Płocku, Stowarzyszenie Archiwistów Polskich, Oddział w Płocku, ss. 154,5 nlb.

Pierwszy numer czasopisma wydanego przez Archiwum Państwowe w Płocku i oddział płocki Stowarzyszenia Archiwistów Polskich jest pomyślany jako forum dla regionalnych badaczy, nie tylko historyków, pracujących na źródłach archiwalnych z zasobu archiwum płockiego, ale również pracowników AP w Płocku. Pierwszy numer został dedykowany zmarłej niespodziewanie 
w 2009 r. wieloletniej dyrektorce AP w Płocku Czesławie Gąsce. W tym numerze problematyki archiwistycznej dotyczą cztery teksty, w tym jedna recenzja.

A. Wojciechowska, Dokumentacja sądowa w Archiwum Państwowym w Ptocku - rys historyczny i stan zachowania (na dzień 30.10.2007 r.), s. 27-40); [rec.] ks. Dariusz Majewski, Inwentarz ksiag metrykalnych Archiwum Diecezjalnego w Ptocku, Ptock 2006, wyd. Ptocki Instytut Wydawniczy, ss. 184, A. Wojciechowska, s. 133-136; K. Bańka, Dziatalność Archiwum Państwowego w Ptocku w roku 2008, s. 145-152; L. Franciszkiewicz, Czestawa Gaska (1940-2009), s. 153-155.

„Prace Historyczno-Archiwalne”, t. 22, red. nacz. J. Basta, Rzeszów 2010, wyd. Archiwum Państwowe w Rzeszowie, Polskie Towarzystwo Historyczne, Oddział w Rzeszowie, ss. 274, 2 nlb.

W trzech działach tomu - „Artykuły i opracowania”, „Materiały i źródła” oraz „Recenzje i omówienia”, dwa artykuły dotyczące kwestii kancelaryjno-archiwalnych.

R. Czupryk, Wizytacje dekanalne przemyskiej eparchii jako przyktad "latynizmu prawnego" Kościota unickiego w XVIII wieku, s. 17-24; S. Rejman, Ludwik Klemens Topolski-sekretarz rzeszowskiego magistratu i Rady Miejskiej w latach 1885-1903, s. 35-48.

„Przegląd Archiwalny Instytutu Pamięci Narodowej”, t. 3, red. nacz. J. Bednarek, Warszawa 2010, wyd. Instytut Pamięci Narodowej - Komisja Ścigania Zbrodni przeciwko Narodowi Polskiemu, ss. 384, ilustr., sum.

Na tom składają się teksty umieszczone w sześciu działach: „Archiwum”, „Zasób archiwalny”, „Dokumenty”, „Varia”, „Recenzje” oraz „Kronika”. Część artykułów ma charakter historyczny i dotyczy problematyki udokumentowanej w zasobach archiwalnych IPN. Z prac poświęconych problematyce archiwalnej należy wymienić siedem tekstów, w tym jedną recenzję.

A. Marcinkiewicz, Sposób archiwizowania i przechowywania dokumentacji $w$ Zarzadzie II Sztabu Generalnego Wojska Polskiego, s. 9-50; D. Burczyk, Metody opracowania i rekonstrukcji zespotu archiwalnego Wojskowy Sąd Rejonowy w Gdańsku (1946-1955), s. 51-78; T. Ruzikowski, Zarys historii Zintegrowanego (Zautomatyzowanego) Systemu Kartotek Operacyjnych resortu spraw wewnętrznych, s. 79-116; R. Dyrcz, R. Kotarba, Spuścizna Wincentego Heina, s. 117-143; A. Zieliński, Przyktady dokumentacji wytworzonej przez pion ewidencji operacyjnej SB w latach 1972-1990 i jej wykorzystanie do badań naukowych, s. 147-168; W. Krupa, J. Łabowicz, Informacja o dokumentacji pochodzacej z tzw. worków ewakuacyjnych 
przekazanych przez Urząd Ochrony Państwa do zasobu archiwalnego Oddziatu Instytutu Pamięci Narodowej w Katowicach, s. 197-204; [rec.] Informator o zasobie archiwalnym Centralnego Archiwum Wojskowego, praca zbiorowa pod redakcja Natalii Bujniewicz, Warszawa 2008, ss. $728+$ wktadka ilustracyjna, R. Leśkiewicz, s. 341-344.

„Rocznik Augustowsko-Suwalski”, t. 10, red. nacz. A. Matusiewicz, Suwałki 2010, wyd. Augustowsko-Suwalskie Towarzystwo Naukowe, Muzeum Okręgowe w Suwałkach, Archiwum Państwowe w Suwałkach, ss. 279, 1 nlb.

Zdecydowana większość prac publikowanych w roczniku jest poświęcona problematyce regionalnej. Jedynie sprawozdanie z działalności suwalskiego archiwum dotyka rzeczywistości archiwalnej.

Archiwum Państwowe w Suwatkach, oprac T. Radziwonowicz, s. 249-253.

„Rocznik Historyczno-Archiwalny”, t. 21, red. B. Bobusia, Przemyśl 2010, wyd. Archiwum Państwowe w Przemyślu, ss. 388, ilustr., sum, Zusam., sod.

Wydany z okazji 135. rocznicy powstania Archiwum Miejskiego i 60. rocznicy powstania Archiwum Państwowego w Przemyślu, czyli upaństwowienia Archiwum Miejskiego. Tradycyjnie znaczna część publikowanych tu prac to krótkie studia historyczne, choć oprócz nich znalazły się także teksty z zakresu archiwistyki i dziedziny archiwalnej.

E. Grin-Piszczek, Kopiariusz rodziny Trzecieskich z zasobu Archiwum Państwowego w Przemyślu, s. 147-159); A. K. Mielnik, Materiaty rodziny Porembalskich w zasobie Archiwum Państwowego w Przemyślu, s. 161-174); T. Szulc, Materiaty źródtowe do dziejów harcerstwa przemyskiego w latach 1908-1950 w zasobie Archiwum Państwowego w Przemyślu, s. 175-182; M. Paszkiewicz, Zasoby sanockiego oddziatu Archiwum Państwowego w Rzeszowie dotyczace pozostatości mienia poukraińskiego w powiecie sanockim po okresie przesiedleń 1947 roku, s. 183-193; Sprawozdanie z dziatalności Archiwum Państwowego w Przemyślu za 2007 rok, oprac. B. Bobusia, M. Dalecki, s. 295-302; Sprawozdanie z dziatalności Archiwum Państwowego w Przemyślu za 2008 rok, oprac. M. Dalecki, M. A. Nowak, s. 303-310; Materiaty do bibliografii Archiwum Państwowego w Przemyślu za 2007 i 2008 rok, oprac. M. Dalecki, E. Długosz, s. 311-315; M. Dalecki, Wystawa „O niepodlegta Polske i granice 1914-1920. Archiwalia ze zbiorów Archiwum Państwowego w Przemyślu", s. 317-318; A. Kiełt, Wystawa "Pięc minut przed burza... II wojna światowa w dokumentach z zasobu Archiwum Państwowego w Przemyślu" oraz sesja naukowa "Wrzesień 1939 r. w regionie przemyskim” (Przemyśl, 4-5 IX 2009 r.), s. 319-320; Bibliografia zawartości "Rocznika Historyczno-Archiwalnego", t. 1-20, oprac. E. Długosz, s. 345-372. 


\section{„Szkice Archiwalno-Historyczne”, nr 6, red. nacz. P. Greiner, Katowice 2010, wyd. Archiwum Państwowe w Katowicach, ss. 199}

P. Greiner, Plany miast pruskiego Górnego Śląska z lat 1810-1811/1815, s. 11-25 (jest to katalog planów); P. Snoch, Kancelaria miasta Sosnowca w latach 1916-1939, s. 27-34; S. Krupa, A. Staszków, Personel Staatsarchiv Kattowitz w latach 1939-1945 w świetle ich akt osobowych, s. 101-116; T. Szafron, R. Miłoch, Akta osobowo-ptacowe jako przyktad źródta do badań nad historia PRL, s. 145-148; Sprawozdanie dyrektora Archiwum Państwowego w Katowicach za 2009 rok, s. 173-185; S. Klimkiewicz, Zarzadzanie projektem „Ochrona i konserwacja Cieszyńskiego Dziedzictwa Piśmienniczego" w Archiwum Państwowym w Katowicach, s. 187-193.

\section{„Teki Archiwalne”. Seria nowa, t. 10 (32), przew. kom. red. E. Kołodziej, Warszawa 2009 [druk 2010], ss. 439}

Artykuły: D. M. Groszek, Archiwa w Wielkiej Brytanii-organizacja i dziatalność, s. 5-29; K. Klimiuk, Archiwa w Stanach Zjednoczonych Ameryki Pótnocnej-organizacja i dziatalność, s. 31-45; W. Stępień, Archiwa państwowe na Stowacji: organizacja, dziatalność, zasoby, s. 47-70; A. Laskowska, Problematyka zespotów ztożonych w polskiej literaturze archiwistycznej, s. 71-102; A. Żmudzińska, Konsulat RP w Marsylii w latach 1919-1940. Organizacja, kancelaria i pozostate po nim akta, s. 103-125; P. Romanowski, Kancelaria Ambasady RP w Londynie w latach 1919-1945 (do 1929 r. Poselstwa), s. 127-138; A. G. Dąbrowski, Projekt przepisów kancelaryjnych dla urzędów administracji publicznej i przedsiębiorstw prywatnych autorstwa Mieczystawa Inesa z grudnia 1930 r., s. 139-156; N. A. Borzęcka, Międzynarodowa Rada Archiwów - organizacja i dziatalność, s. 157-177; A. Makówka, Rola Centralnego Ośrodka Informacji Archiwalnej w systemie informacji archiwalnej w latach 1973-2008, s. 179-195; B. Polkowska, Regulacje prawne dotyczące podmiotów publicznych w zakresie tworzenia, postępowania oraz archiwizowania dokumentów elektronicznych, s. 197-218.

Miscellanea: B. Nowożycki, Meldunki Sytuacyjne IV Rejonu „Reguta” I Obwodu AK Śródmieście z okresu Powstania Warszawskiego, s. 245-270; E. Kołodziej, Korespondencja Józefa Stojanowskiego, kierownika Archiwum Akt Nowych, z Witoldem Suchodolskim, dyrektorem Archiwów Państwowych, z lat 1944-1945 w sprawie ratowania akt archiwów warszawskich, s. 271-286; A. Braun, Spuścizna Stanistawa Grocholskiego (1912-2002), s. 323-330; W. Horst, Zbigniew Szczygielski, archiwista pasjonat i jego spuścizna, s. 331-356; K. Smolana, Archiwalia polskie i polonijne w Argentynie, s. 379-392.

W dziale recenzji zamieszczono krytykę dwóch publikacji.

Tom zamyka Kronika Archiwum Akt Nowych, Bibliografia zawartości „Tek Archiwalnych. Serii nowej" za lata 1996-2006, t. 1 (23)-9 (31), a także nekrologi: Stanisława Klemensa Lelińskiego (1937-2009), Jerzego Michała Stocha (1922-2008) i Bożeny Tazbir-Tomaszewskiej (1923-2006). 


\section{OPRACOWANIA INFORMACYJNE I EDYCJE ŹRÓDEE}

Dokumenty Rządu RP na obczyźnie. Suplementy do tomów I-VIII Protokotów Posiedzeń Rady Ministrów Rzeczypospolitej Polskiej październik 1939-wrzesień 1945, oprac. W. Rojek przy współpracy A. Suchcitza, Kraków 2010, wyd. Oficyna Wydawniczo-Drukarska „Secesja”, ss. 282

Tom publikowanych dokumentów stanowi uzupełnienie ośmiotomowego wydawnictwa zatytułowanego „Protokoły posiedzeń Rady Ministrów RP” obejmującego okres po drugiej wojnie światowej. Zawarto w nim ogłoszone drukiem w całości zarówno nieodnalezione do tej pory formalne załączniki do protokołów, jak i nieoficjalne aneksy ilustrujące kwestie poruszane w protokołach. Tom obejmuje okres od 1 października 1939 r. (to jest od pierwszego posiedzenia Rządu na Uchodźstwie) do 3 lipca 1945 r. (do tego bowiem posiedzenia udało się odnaleźć formalny załącznik). Teksty dokumentów opatrzono nadanym numerem porządkowym właściwym każdemu z protokołów, poprzedzono je także sygnaturami nadanymi uprzednio w Archiwum Instytutu Polskiego i Muzeum im. gen. Sikorskiego w Londynie bądź też Studium Polski Podziemnej. Podano też informację, czy dany tekst jest oryginałem, maszynową kopią, odpisem itp. Opracowanie jest zaopatrzone w dwujęzyczny (polski i angielski) chronologiczny spis publikowanych dokumentów, a także indeksy: osób i geograficzno-rzeczowy.

Wiesław Faber, Sztuka znaku wodnego. Przerysy znaków wodnych z dokumentów przechowywanych w Archiwum Gtównym Akt Dawnych w Warszawie, t. 1, cz. 1: Zbiory Oddziatu III, archiwa rodowe i zbiory prywatne, Warszawa 2010, ss. 229

Katalog zawierający 621 pozycji - przerysów znaków wodnych wykonanych z dokumentów przechowywanych w Oddziale III Archiwum Głównego Akt Dawnych w Warszawie - archiwa rodowe i zbiory prywatne. Autor katalogu - Wiesław Faber jest byłym pracownikiem AGAD, pracował na stanowisku konserwatora, a następnie kierownika Centralnego Laboratorium Konserwacji Archiwaliów. Przerysy pochodzą z akt przechowywanych w następujących zespołach: Archiwum Potockich z Łańcuta, Kapicjana 1, Archiwum Radziwiłłów z Nieborowa, Archiwum Gospodarcze Wilanowskie, Nabytki (XVI-XX w.), Archiwum Ostrowskich z Ujazdu. W katalogu znajdziemy zesta- 
wienie dat powstania poszczególnych dokumentów, a także tabelę przerysów znaków wodnych odwzorowanych w skali 1:1 wraz z opisem zawierającym: liczbę znaków na karcie, nazwę zespołu akt, sygnaturę akt, stronę. Tekst uzupełniający katalog jest dwujęzyczny - polski i angielski, tabele zostały opisane w języku polskim. Publikacji towarzyszy także obszerna bibliografia dotycząca znaków wodnych.

Instrukcje pracy kontrwywiadowczej Wojskowej Stużby Wewnętrznej wraz $z$ instrukcjami prowadzenia dokumentacji i ewidencji (1957-1990), oprac. B. Kapuściak, Kraków 2010, wyd. Instytut Pamięci Narodowej - Komisja Ścigania Zbrodni przeciwko Narodowi Polskiemu, ss. 527, 1 nlb.

Drugi tom serii wydawniczej „Normatywy Aparatu Represji”, publikującej edycje materiałów z zasobu IPN. We wstępie znajdują się części zawierające charakterystykę materiałów operacyjnych, ewidencję oraz zasady pracy archiwum WSW. Wymienione w tytule tomu instrukcje prowadzenia dokumentacji i ewidencji, opublikowane w wydawnictwie, to „Instrukcja o prowadzeniu dokumentacji i ewidencji kontrwywiadowczej w Wojskowej Służbie Wewnętrznej” z 8 lipca 1971 r., „Instrukcja o prowadzeniu dokumentacji i ewidencji kontrwywiadowczej w Wojskowej Służbie Wewnętrznej” z 14 stycznia 1987 r., „Tymczasowe wytyczne w sprawie prowadzenia dokumentacji i ewidencji kontrwywiadowczej” z 22 lutego 1990 r. oraz „Wykaz dokumentów kwalifikujących się do pozostawienia w aktach operacyjnych” z 4 października 1985 r.

Inwentarz akt wydziatów i studiów Uniwersytetu Jana Kazimierza we Lwowie do roku 1939, t. 2, oprac. J. Wołczański, Kraków 2010, wyd. Wydawnictwo Naukowe Uniwersytetu Papieskiego Jana Pawła II, ss. 781

Na zawartość drugiego tomu inwentarza akt Uniwersytetu Jana Kazimierza we Lwowie (tom pierwszy ukazał się w 2009 r.) składają się inwentarze w ramach sześciu grup tematycznych: 1) teczki osobowe kadry dydaktyczno-naukowej i urzędników uniwersyteckich, 2) wykaz prac naukowych, artykułów, recenzji oraz referatów pracowników naukowych i studentów, 3) akta wytworzone przez rektorat w latach 1850-1899, 4) akta wytworzone przez rektorat w latach 1900-1920, 5) akta wytworzone przez rektorat w latach 1921$-1939,6)$ akta rektoratu $\mathrm{z}$ lat $1817-1849$. 
Inwentarz archiwalny parafii rzymskokatolickiej pw. św. Michata Archanioła w Świebodzinie do 1945 r., oprac. T. Kałuski, Świebodzin 2010, wyd. Muzeum Regionalne w Świebodzinie, ss. 120, ilustr.

Zebrane w ramach omawianego inwentarza archiwalia przechowywane są obecnie w zasobie Archiwum Diecezjalnego w Zielonej Górze, w sumie jest to 609 j.a. (7, 42 m.b.). Większość archiwaliów pochodzi z XIX i XX w. Archiwalia starsze są dziś przechowywane również w zasobie Archiwum Archidiecezjalnego we Wrocławiu.

Inwentarz akt Policji Województwa Śląsiego [1911] 1922-1939, oprac. E. Długajczyk, Katowice 2010, wyd. Archiwum Państwowe w Katowicach, ss. 132, ilustr.

Wydawnictwo ma charakter typowego inwentarza archiwalnego, poprzedzonego wstępem (dzieje ustrojowe twórcy zespołu, dzieje zespołu, charakterystyka archiwalna zespołu, kancelaria i metoda uporządkowania akt, zawartość akt). Opisywany zespół liczy 718 j.a. (16,5 m.b.) ujętych w ramach 15 serii. Na opis jednostkowy składają się: sygnatura bieżąca, dawna sygnatura, tytuł i daty skrajne. Inwentarz zaopatrzono w indeks miejscowości, osobowy i nazw instytucji życia publicznego. Do pracy załączono również fotografie przykładowych archiwaliów.

Katalog Archiwum Profesora Floriana Śmieji, oprac. J. Pasterska, Rzeszów 2010, wyd. Pracownia Badań i Dokumentacji Kultury Literackiej, ss. 122, ilustr.

Publikacja zasadniczo zawiera charakterystykę zawartości archiwum osobistego prof. Floriana Śmieji, iberysty, wieloletniego wykładowcy na Uniwersytecie Ontario w London (Kanada). W 2009 r. za pośrednictwem Konsulatu Generalnego RP w Toronto prof. Śmieja przekazał duży zbiór dokumentów odzwierciedlających jego życie literackie i kulturalne na emigracji Pracowni Badań i Dokumentacji Kultury Literackiej działającej w Instytucie Filologii Polskiej Uniwersytetu Rzeszowskiego. Oprócz trzech artykułów o charakterze wspomnieniowym na zawartość tomu składa się opis zawartości archiwum prof. Śmieji w ramach następujących grup tematycznych: Tomiki poetyckie Floriana Śmieji, Inne książki autorskie, Artykuły profesora Floriana Śmieji w języku polskim, Rękopisy. Maszynopisy (z wyjątkiem reportaży), Reportaże, Książki i artykuły Floriana Śmieji w języku angielskim, Przekła- 
dy, Korespondencje, Książki innych autorów, Artykuły innych autorów, Czasopisma, Hispanika, Inne materiały, Fotografie. Jako aneks dołączono do publikacji informację o zasadach korzystania z „Archiwum Profesora Floriana Śmieji”.

Katalog mikrofilmów katolickich ksiąg metrykalnych parafii diecezji gliwickiej do 1920 roku, oprac. J. Bonczol, Gliwice 2010, wyd. Archiwum Diecezjalne w Gliwicach, ss. 149

Publikacja zawiera zestawienie mikrofilmów ksiąg metrykalnych parafii z terenu diecezji gliwickiej (utworzonej w 1992 r.). Akcję mikrofilmowania przeprowadzono w latach 1998-2001 przy współudziale Towarzystwa Genealogicznego z Utah Kościoła Jezusa Chrystusa Świętych w Dniach Ostatnich. W sumie zmikrofilmowano 1203 księgi metrykalne prowadzone do $1945 \mathrm{r}$. Oryginał mikrofilmu znajduje się w rękach mormońskiego Towarzystwa Genealogicznego w Utah, natomiast kopie w archiwum bieżącym kurii w Gliwicach. Mikrofilmowane księgi (z 18 dekanatów) są obecnie przechowywane w zasobach archiwów parafialnych.

Katalog rękopisów Biblioteki Publicznej im. Hieronima Łopacińskiego w Lublinie, cz. 7, Sygnatury 2811-2929, oprac. pod kier. E. Kurpińskiej, Lublin 2010, wyd. Wojewódzka Biblioteka Publiczna im. Hieronima Łopacińskiego w Lublinie, ss. 158

Prócz rękopisów ewidentnie bibliotecznych, w katalogu ujęto wiele materiałów o charakterze archiwaliów, jak allegata do akt stanu cywilnego parafii grekokatolickiej w Łomazach z 1812 r., archiwum osobiste Tadeusza Witkowskiego z lat 1916-1988, zawierające także dokumentację Stowarzyszenia Architektów Polskich, Związku Polskich Artystów Fotografików i materiały Stanisława Noakowskiego, archiwum osobiste Jerzego Albina de Tramecourt z lat 1917-1989, liczne szczątkowe akta cechów, osób, rodzin i majątków. W niektórych przypadkach dałoby się wskazać zespoły archiwalne, w których jest miejsce dla rękopisów opisanych w katalogu. Refleksja, która może się budzić u archiwisty studiującego biblioteczne katalogi: głębia opisu materiałów zależy od przypadkowego ich zgromadzenia w różnego rodzaju instytucjach. Weźmy allegata do akt stanu cywilnego. W archiwach jest ich nieskończenie więcej, ale nikt nie może sobie pozwolić na tak drobiazgowe opracowanie każdego pojedynczego dokumentu. Porównywalnie z archiwa- 
mi niewielka liczba rękopisów bibliotecznych powoduje, że ci, którzy mieli szczęście, że materiały ich dotyczące trafiły do bibliotek, mają większą szansę na zachowanie pamięci o sobie. Taki paradoks - nagroda dla tych, których archiwalia zarchiwizowały się „niewłaściwie”.

Katalog zbiorów Muzeum Technik Ceramicznych w Kole, red. K. Witkowski, Koło-Kielce 2010, wyd. Muzeum Technik Ceramicznych w Kole, NEW Fine Grain, ss. 95, ilustr.

Katalog zawiera opis różnego rodzaju eksponatów zgromadzonych w zbiorach kolskiego Muzeum Technik Ceramicznych. Nie ujmuje on całości zbioru, a wybrane obiekty zostały opisane w ramach działów: archeologicznego, artystycznego, etnograficznego i historycznego (między innymi archiwalia).

Małgorzata Klimas, Bożena Lesiak-Przybył, Anna Sokół, Wielki Kraków. Rozszerzenie granic miasta w latach 1910-1915. Wybrane materiaty ze zbiorów Archiwum Państwowego w Krakowie, Kraków 2010, wyd. Archiwum Państwowe w Krakowie, cz. 1, ss. 348, ilustr.; cz. 2, 4 mapy

Wydawnictwo zostało przygotowane z myślą o uczczeniu setnej rocznicy rozszerzenia granic administracyjnych Krakowa w 1910 r. W tym czasie przyłączono do Krakowa kilkanaście gmin i obszarów dworskich, a także rozstrzygnięto konkurs na „Plan regulacji Wielkiego Krakowa”. Publikacja składa się z dwóch części. Pierwsza ma charakter albumowy. Tworzą ją teksty poświęcone m.in. Juliuszowi Leo, twórcy idei Wielkiego Krakowa i wiceprezydentowi tego miasta, rozwojowi terytorialnemu Krakowa w latach 1910-1915 oraz poszczególnym gminom i miastu Podgórz, przyłączonym w tym okresie do Krakowa. Teksty są bogato ilustrowane materiałem archiwalnym w postaci zdjęć, planów, map z zasobu Archiwum Państwowego w Krakowie. Część druga wydawnictwa to reprodukcje trzech projektów konkursowych przedstawionych w ramach konkursu na plan regulacyjny Wielkiego Krakowa z 1910 r. oraz planu Krakowa z oznaczonymi granicami Wielkiego Krakowa z 1916 r. Wszystkie teksty są napisane w języku polskim i angielskim. 
Agnieszka Kłys, Informator o zasobie archiwalnym Muzeum Stutthof, Warszawa-Sztutowo 2010, wyd. Naczelna Dyrekcja Archiwów Państwowych, Muzeum Stutthof, ss. 29, ilustr.

Informator charakteryzuje zasób archiwum Muzeum Stutthof, który liczy 69 tys. j.a. (125 m.b.). Największy fragment zasobu tworzą akta zespołu Konzentrationslager Stutthof (67 828 j.a., 116 m.b., z czego aż 66162 j.a. to akta personalne więźniów). Na zasób archiwum składają się również zbiory archiwaliów w ramach działów: Ankiety byłych więźniów, Dokumentacja byłych więźniów, Relacje i wspomnienia, Zbiory, Kolekcje. Informator ujmuje tylko spis akt zespołu Konzentrationslager Stutthof (z pominięciem teczek osobowych). Na opis jednostkowy w ramach informatora składają się: sygnatura archiwalna, tytuł jednostki archiwalnej, daty, uwagi.

Kościoty Archidiecezji Katowickiej. Ze zbiorów pocztówek archiwalnych Biblioteki Śląskiej, oprac. T. Roszkowska, W. Pawłowicz, Katowice 2010, wyd. Biblioteka Śląska w Katowicach, s. nlb., ilustr.

Wydawnictwo w całości, nie licząc trzystronicowego wstępu „Śląska pocztówka sakralna" autorstwa Jana Malickiego, stanowią reprodukcje pocztówek wydanych przed 1945 r. z wizerunkami śląskich kościołów. Wybór pocztówek nie jest według autorów przypadkowy - ukazują one „najważniejsze świątynie Archidiecezji, współtworzące swoisty szlak peregrynacyjny po zabytkach". Wszystkie reprodukowane pocztówki pochodzą ze zbiorów Biblioteki Śląskiej, liczących obecnie około 45 tys. obiektów.

\section{Ojczyzna w obiektywie. Imponderabilia kronikarza Juliusza L. Englerta} na emigracji, red. A. Biernat, W. Stępniak, Warszawa 2010, wyd. Naczelna Dyrekcja Archiwów Państwowych, s. 113, 19 nlb., ilustr.

Juliusz L. Englert (zm. 2010 r.) jest powszechnie uznawany za kronikarza polskiej emigracji w Wielkiej Brytanii, sięgającej rodowodem czasów drugiej wojny światowej. Był jednak związany nie tylko z emigracją angielską, ale również amerykańską. Pozostawił po sobie olbrzymi, liczący grubo ponad 100 tys., zbiór negatywów fotografii obrazujących działalność i życie polskiej emigracji po drugiej wojnie światowej. W większości ten cenny zbiór przekazał na krótko przed śmiercią Archiwum Dokumentacji Mechanicznej (obecnie Narodowe Archiwum Cyfrowe). Zanim zakończone zostaną prace nad 
skatalogowaniem całego zbioru, Naczelna Dyrekcja Archiwów Państwowych postanowiła opublikować jego część - w formie księgi jubileuszowej dedykowanej jego twórcy. Na publikację składają się teksty poświęcone najbliższej rodzinie Juliusza Englerta, wspomnienia o nim członków rodziny i znajomych, charakterystyka archiwum fotograficznego Juliusza Englerta autorstwa dyrektora Narodowego Archiwum Cyfrowego w Warszawie Krzysztofa Pątka, bibliografia jego prac.

Plany twierdzy Przemyśl, cz. 3, oprac. B. Bobusia, M. Gosztyła, L. Lichołai, Przemyśl 2010, wyd. Archiwum Państwowe w Przemyślu, Przemyskie Towarzystwo Archiwistyczne „Archiwariusz” w Przemyślu. Stowarzyszenie Opieki nad Twierdzą Przemyśl i Dziedzictwem Kulturowym Ziemi Przemyskiej, ss. 160, ilustr.

Jest to część trzecia publikacji „Plany Twierdzy Przemyśl”, która stanowi kontynuację podjętej kilka lat wcześniej próby naszkicowania przeobrażeń urbanistycznych i architektonicznych, jakie zaszły w Przemyślu i okolicy miasta w okresie kilkudziesięciu lat budowy twierdzy. Ilustracje zamieszczone w albumie pochodzą z zasobu Archiwum Państwowego w Przemyślu, wszystkie zostały ponumerowane i opisane ze wskazaniem, gdzie są przechowywane. Prezentowaną w publikacji infrastrukturę twierdzy z okresu jej budowania przedstawiono w granicach czterech rejonów: Centrum - Grabarza - ul. Mickiewicza i Lwowska; ul. Dworskiego, Smolki, Nestora, Słowackiego; ul. Przemysłowa - Zniesienie; Zasanie.

Portret miasta. Architektura Kalisza $w$ dokumentach archiwalnych, red. G. Schlender, J. A. Splitt, Kalisz 2010, wyd. Archiwum Państwowe w Kaliszu, ss. 315, ilustr.

Wydawnictwo powstało w ramach przygotowań do wystawy „Portret miasta. Architektura Kalisza w dokumentach archiwalnych” zorganizowanej wspólnie przez Archiwum Państwowe w Kaliszu i Muzeum Okręgowe Ziemi Kaliskiej. Na jego treść składają się krótkie teksty poświęcone panoramom Kalisza, mapom i planom tego miasta, Ratuszowi i Głównemu Rynkowi, świątyniom, parkom, placom, mostom i ulicom oraz innym wybranym obiektom architektonicznym Kalisza, zobrazowanym różnego rodzaju źródłami ikonograficznymi. 
Danuta Stępniewska, Meldunki miesięczne wywiadu przemystowego KG ZWZ/AK 1941-1944. Aneks. Szefowie, kierownicy i wspótpracownicy Biura Studiów Wywiadu Przemystowego Oddziatu II KG ZWZ/AK, Warszawa 2010, wyd. Naczelna Dyrekcja Archiwów Państwowych, ss. 62

M.in. biogramy Joanny Bronisławy Fabiszewskiej (1906-1982), pracującej w archiwum Biura Studiów Przemysłowych (s. 26). i Marianny Możdżeńskiej (1905-1987), kierowniczki tego archiwum (s. 33).

Sumariusz Metryki Koronnej. Seria nowa, red. W. Krawczuk, t. 4: Księga wpisów podkanclerzego Wojciecha Baranowskiego z okresu marzec 1588 -grudzień 1590 MK 135 z Archiwum Gtównego Akt Dawnych w Warszawie, oprac. W. Krawczuk, M. Kulecki, Warszawa 2010, wyd. DiG, ss. 480

To czwarty z kolei tom serii nowej sumariusza Metryki Koronnej, dzieła zainicjowanego i prowadzonego przez Wojciecha Krawczuka. Udostępnienie kolejnych tomów Metryki Koronnej przez streszczenia dokumentów w nich zawartych może tylko cieszyć i nie wymaga specjalnej rekomendacji czy uzasadnienia. Zwłaszcza że autorami są dwaj niekwestionowani znawcy Metryki Koronnej, którzy wielokrotnie sprawdzili się też jako edytorzy źródeł historycznych. Omawiany tom przynosi obszerny materiał (streszczenia 1086 dokumentów) do bardzo ważnego okresu w dziejach Polski nowożytnej, okresu formowania się systemu rządów władcy, który miał panować wiele dziesięcioleci. Sami wydawcy nawiązują do wydawnictwa Archiwum Jana Zamoyskiego, urywającego się właśnie na 1588 r. W jakimś sensie opublikowany sumariusz udostępnia więc dokumenty z okresu nieco słabiej oświetlonego łatwo dostępnymi źródłami drukowanymi. I rzeczywiście, książka przynosi ważny materiał do kształtowania się stronnictwa regalistycznego Zygmunta III Wazy. Analiza księgi, którą wydawcy zregestowali, stanowi także ciekawy przyczynek do dziejów kancelarii koronnej. Dlaczego metrykant Stanisław Radecki sformował taką wyjątkowo obszerną księgę, niezgodnie z ukształtowanymi już obyczajami kancelaryjnymi? Inna rzecz: z jakiego np. powodu tak rozbudowana jest narracja nadania dla sekretarza królewskiego Jana Skrzetuskiego? Warto zauważyć, że ostatnio Agnieszka Rosa wskazała na samoświadectwowy (egodokumentalny) charakter Metryki Koronnej w odniesieniu do personelu kancelaryjnego. Tu mamy kolejny dowód na potwierdzenie tego zjawiska. Koncepcja serii nowej sumariusza Metryki Koronnej jest już znana w środowisku naukowym, a tym, którzy zetknęli się z nią pierwszy 
raz, Wojciech Krawczuk przybliża ją we wstępie. Konstruowanie regestów jest realizacją sprawdzonego już modelu i nie budzi zastrzeżeń.

Testamenty mieszczan warszawskich od XV do końca XVII wieku: katalog, oprac. A. Bartoszewicz, A. Karpiński, K. Warda, Warszawa 2010, wyd. Semper, ss. 99

Katalog „Testamenty mieszczan warszawskich od XV do końca XVII wieku” stanowi efekt kwerendy przeprowadzonej w Archiwum Głównym Akt Dawnych w całości zachowanych akt tworzących „Archiwum miasta Warszawy”. Przebadano łącznie 375 testamentów z lat 1431-1699 sporządzonych jako dyspozycja ostatniej woli mieszczan Starej i Nowej Warszawy, a także mieszkających tu przedstawicieli innych stanów oraz przybyszów z kraju i zagranicy, którzy sporządzili i uwierzytelnili swój testament przed warszawskimi urzędami. Celem kwerendy było zinwentaryzowanie i skatalogowanie dyspozycji ostatniej woli zebranych w warszawskim archiwum miejskim. Uwzględnione w katalogu testamenty zostały odnalezione w jednostkach archiwalnych przechowywanych w kilku zespołach AGAD: Zespół Stara Warszawa - księgi radzieckie, księgi ławniczo-wójtowskie, księgi testamentów, inwentarzy i taksacji dóbr; Zespół Nowa Warszawa - księgi radzieckie, księgi ławnicze; Zespół Warszawa Ekonomiczne; Zbiór dokumentów pergaminowych. Katalog składa się z 339 pozycji, w których odnotowano 375 testamentów. Ma układ chronologiczny. Każda pozycja zawiera następujące informacje: kolejny numer; data sporządzenia oryginału (bądź wpisu do ksiąg miejskich); imię i nazwisko testatora, jego zawód, ewentualnie miejsce pochodzenia, pełnione funkcje w radzie i ławie, w przypadku kobiet także informacje o mężu; zachowana forma przekazu i sygnatura; język, w którym sporządzono akt ostatniej woli; informacje uzupełniające - np. odstępstwa od normy kancelaryjnej, istnienie kopii lub innych wersji testamentu, unieważnienie, wniesione poprawki, wyjaśnienia problemów z datacją, informacje o edycji źródłowej, odsyłacze do znajdujących się w aktach i odnalezionych w trakcie kwerendy inwentarzy, spisów nieruchomości czy podziałów majątku zmarłego testatora, odsyłacze do literatury przedmiotu. Katalog ponadto jest zaopatrzony w trzy indeksy: osobowy, geograficzny i rzeczowy.

Włodzimierz Pfeiffer, Sentymentalna podróż po Łodzi. Łódź na starych fotografiach Wtodzimierza Pfeiffera, wstęp i podpisy pod zdj. R. Bonisław- 
ski, Łódź 2010, wyd. Wydawnictwo Hamal Andrzej Machejek, Archiwum Państwowe w Łodzi, ss. 192

Album fotografii międzywojennej Łodzi autorstwa Włodzimierza Pfeiffera (1890-1941). Oryginalne klisze szklane są przechowywane w Archiwum Państwowym w Łodzi w zespole Archiwum Włodzimierza Pfeiffera (księgarza i fotografa łódzkiego) z lat 1916-1939. Wyboru fotografii dokonali Julian Baranowski, Ryszard Bonisławski, Andrzej Machejek i Piotr Zawilski. Wstęp i podpisy pod zdjęciami opracował Ryszard Bonisławski. Tekst został opracowany w języku polskim i angielskim. Publikacja zawiera także załączoną kopię międzywojennego planu wojewódzkiego miasta Łodzi.

Marcin Wodziński, Judaica w aktach Centralnych Wtadz Wyznaniowych Królestwa Polskiego Archiwum Gtównego Akt Dawnych. Informator archiwalny, Wrocław 2010, wyd. Wydawnictwo Uniwersytetu Wrocławskiego, ss. 262, ilustr.

Zespół archiwalny to nie jest, bo takiego urzędu nie było. Centralny zarząd spraw wyznaniowych sprawowały kolejno różne urzędy ministerialne (Komisja Rządowa Wyznań Religijnych i Oświecenia Publicznego, Komisja Rządowa Spraw Wewnętrznych, Duchownych i Oświecenia Publicznego, Komisja Rządowa Spraw Wewnętrznych i Duchownych), w których funkcjonowały czy to Wydział Wyznań Religijnych, czy Wydział Wyznań i Oświecenia Publicznego, czy Wydział Spraw Duchownych. Objęty informatorem „zespół” liczy 1995 jednostek archiwalnych. Sprawy żydowskie znaleziono w 491 jednostkach. Autor nazywa swoje dzieło „informatorem czy przewodnikiem tematycznym" (s. 10), podczas gdy opisy jednostek archiwalnych określa jako inwentarz. W rzeczywistości więc jest to katalog archiwalny, którego zakres obejmuje jeden „zespół archiwalny”, kryterium wyboru jednostek do opisania w katalogu była tematyka żydowska, przedmiotem opisu jest jednostka archiwalna, a układ opisów jest zgodny z układem „zespołu archiwalnego”. Schemat opisu jednostki archiwalnej jest następujący: 1. sygnatura archiwalna, 2. tytuł jednostki, 3. liczba stron, 4. daty skrajne, 5. analiza zawartości jednostki. Publikacja została wyposażona w indeksy: osób, nazw geograficznych i rzeczowy. Czemu służy „Wykaz jednostek zawierających dane o ludności żydowskiej i uwzględnionych w niniejszym informatorze”, powielający dokładnie „inwentarz” z wyłączeniem analizy zawartości jednostek, tak do końca nie wiadomo. 
Żotnierze Września polegli i pomordowani na Wschodzie, red. A. Wesołowski przy współudz. K. Stepana, Warszawa 2010, wyd. Ministerstwo Obrony Narodowej, Centralne Archiwum Wojskowe, ss. 400, ilustr.

Alfabetycznie ułożone krótkie biogramy z edycją i podobiznami materiałów archiwalnych dotyczących tych osób, niekoniecznie z września, również np. z wojen lat 1919-1920.

\section{ZBIORY STUDIÓw}

Archiwa - nowe problemy, nowe rozwiąania. XVII Konferencja Archiwów Instytucji Kulturalnych i Naukowych Stowarzyszenia Archiwistów Polskich, Stupsk-Ustka, 7-9 czerwca 2009 r., red. A. Krzemińska, Słupsk-Kraków 2010, ss. 84

Tom pokonferencyjny XVII Ogólnopolskiej Konferencji Sekcji Archiwów Instytucji Naukowych i Kulturalnych Stowarzyszenia Archiwistów Polskich obejmuje 11 referatów o różnorodnej tematyce, oscylującej jednak wokół tematu przewodniego konferencji - „Archiwa - nowe problemy, nowe rozwiązania”. Dziesięć prac dotyczy spraw archiwalnych.

H. Robótka, Nowa organizacja zarządzania przedarchiwalnego, s. 7-13; I. Kwiatkowska, Historii nie tylko strażnicy, s. 14-16; A. Laszuk, Standardy opisu archiwalnego w kontekście nowego prawa archiwalnego, s. 17-14; A. Domalanus, Wptyw archiwum uczelnianego na ksztattowanie zasobu na przyktadzie Archiwum Uniwersytetu im. Adama Mickiewicza w Poznaniu, s. 25-27; E. Kłapcińska, Opracowywanie akt osobowych w Archiwum Uniwersytetu Wroctawskiego, s. 28-42; J. Kapitan, Problemy gromadzenia i opracowywania akt osobowych $w$ Katolickim Uniwersytecie Lubelskim Jana Pawta II, s. 43-49; A. Krzemińska, Problematyka akt osobowych w archiwach panistwowych, s. 50-57; G. Socik, Zasady opracowania Kolekcji Akt Personalnych i Odznaczeniowych z lat 1918-1939, s. 58- 67; S. Marchel, Archiwum historyczne jako przestrzeń komunikacji międzykulturowej, s. 68-73; D. Kwiatkowski, Rola archiwum $w$ żyiu regionu, s. 74-76.

Dziedzictwo archiwalne we wspótpracy Polski i Ukrainy, red. W. Stępniak, Warszawa 2010, wyd. Naczelna Dyrekcja Archiwów Państwowych, Państwowy Komitet Archiwów Ukrainy, ss. 239

Tom powstał jako efekt współpracy polskiej i ukraińskiej administracji archiwalnych. Jest podzielony na dwie części. Pierwsza zawiera publikacje oficjalnych dokumentów wypracowanych przez obie strony, a dotyczących archiwa- 
liów historycznych z lat 1996-2008 (w polskiej i ukraińskiej wersji językowej) oraz teksty dwóch opracowań, napisanych przez Jacka Krochmala i Władysława Stępniaka. W drugiej opublikowano materiały przygotowane w związku z seminarium „Polsko-ukraińskie wspólne dziedzictwo archiwalne” (Warszawa-Płock, 12-13 września 2005). Ukraiński tytuł tomu: Архівна спадщна у співпраці Польщі і Украӥни.

Część I (podano tylko teksty w języku polskim) - Porozumienie między Rządem Rzeczypospolitej Polskiej a Rządem Ukrainy o wspótpracy $w$ dziedzinie ochrony i zwrotu dóbr kultury utraconych i bezprawnie przemieszczonych podczas II wojny światowej (Warszawa, 25 czerwca 1996 r.), s. 19-21; Protokót pierwszego posiedzenia Międzyrządowej Komisji Polsko-Ukraińskiej do spraw ochrony i zwrotu dóbr kultury utraconych i bezprawnie przemieszczonych podczas II wojny światowej (Lwów, 15 maja 1997 r.), s. 27-28; Protokót drugiego posiedzenia Międzynarodowej Komisji Polsko-Ukraińskiej do spraw ochrony i zwrotu dóbr utraconych i bezprawnie przemieszczonych podczas II wojny światowej (Warszawa, 19 lutego 1999 r.), s. 31-32; Protokót trzeciego posiedzenia Międzynarodowej Komisji Polsko-Ukrainskiej do spraw ochrony i zwrotu dóbr utraconych i bezprawnie przemieszczonych podczas II wojny światowej (Kijów, 6 marca 2001 r.), s. 37-39; Protokót czwartego posiedzenia Międzynarodowej Komisji Polsko-Ukraińskiej do spraw ochrony i zwrotu dóbr utraconych i bezprawnie przemieszczonych podczas II wojny światowej (Warszawa, 18 czerwca 2008 r.), s. 45-48; Protokót pierwszego posiedzenia zespotu ekspertów do spraw archiwaliów historycznych w ramach prac Międzyrządowej Komisji Polsko-Ukrainskiej do spraw ochrony i zwrotu dóbr kultury utraconych i bezprawnie przemieszczonych podczas II wojny światowej (Kraków, 16 lutego 2001 r.), s. 55-58; Protokót drugiego posiedzenia zespotu ekspertów do spraw archiwaliów historycznych w ramach prac Międzyrządowej Komisji Polsko-Ukraińskiej do spraw ochrony i zwrotu dóbr kultury utraconych i bezprawnie przemieszczonych podczas II wojny światowej (Krasiczyn, 12 grudnia 2001 r.), s. 63-66; Protokót między Naczelnym Dyrektorem Archiwów Państwowych a Przewodniczącym Państwowego Komitetu Archiwów Ukrainy o restytucji wzajemnej przemieszczonych dóbr kultury (Jaremcze, 1 lipca 2003 r.), s. 71-73; Notatka ze spotkania szefów archiwów państwowych Polski i Ukrainy, odbytego w Archiwum Państwowym w Przemyślu w dniu 13 kwietnia 2006 r., s. 79-81; Protokót w sprawie koncepcji polsko-ukraińskiego wspólnego dziedzictwa archiwalnego. Warszawa, 19-20 maja 2006 r., s. 87-88; J. Krochmal, Polonika w Centralnej Kartotece Zespotów Archiwalnych $w$ Kijowie, s. 91-135; W. Stępniak, UNESCO na rzecz rozstrzygania międzynarodowych sporów o archiwalia, s. 137-154 [zawiera aneks w postaci tłumaczenia dokumentu pt. Organizacja Narodów Zjednoczonych do spraw Oświaty, Nauki i Kultury. Umowy i konwencje: Modele umów i konwencji dwustronnych i wielostronnych o przekazywaniu archiwaliów]; Część II - W. Stępniak, Wspólne dziedzictwo archiwalne, s. 157-168; A. Biernat, Dziatalność zespotu ekspertów do spraw archiwaliów historycznych w ramach prac Międzynarodowej Komisji Polsko-Ukraińskiej do spraw ochrony i zwrotu dóbr kultury utraconych i bezprawnie przemieszczonych podczas II wojny światowej-ocena strony polskiej, s. 169-179; H. Boriak, Wspólne dziedzictwo archiwalne: stanowisko Ukrainy, s. 181-186 (wersja ukraińska tekstu na s. 187-192); J. Krochmal, Metodyka opracowania materiałów archiwalnych tworzących wspólne dziedzictwo archiwalne a doświadczenia archiwistów polskich, s. 193- 
-200; J. Prylepiszewa, Opracowując koncepcję wspólnego dziedzictwa archiwalnego: praca nad „Krajowym rejestrem utraconych i przemieszczonych zbiorów archiwalnych”, s. 201-204 (wersja ukraińska tekstu na s. 205-208); J. Krochmal, Materiaty archiwalne o polskiej proweniencji terytorialnej w zbiorach ukrainskich, s. 209-239.

Dzieje biurokracji na ziemiach polskich, t. 3, cz. 1-2, red. A. Górak, K. Latawiec, D. Magier, Lublin-Siedlce 2010, wyd. Radzyńskie Stowarzyszenie Inicjatyw Lokalnych-Radzyńskie Towarzystwo Naukowe (LIBRA), ss. 735 , ilustr., rez.

Podzielony fizycznie na dwie części tom studiów składa się z kilkudziesięciu tekstów poruszających problemy funkcjonowania biurokracji od XVII w. W znacznej mierze są to prace przybliżające kadry urzędnicze i funkcjonowanie aparatu administracyjnego. Wśród nich znalazły się także artykuły omawiające techniczne aspekty tego procesu, czyli prezentujące mechanizmy pracy kancelaryjnej, informacje o charakterze źródłowym i odnoszące się do dziedziny archiwalnej.

A. Filipczak-Kocur, Kopiariusz kancelarii podskarbinískiej Stefana Paca (1630-1634), s. 51-59; H. Palkij, Kancelaryjne spisy starostw w czasach saskich, s. 61-100; D. Wereda, Źródta do dziejów kancelarii metropolitów unickich $w$ XVIII w., s. 101-113; K. Latawiec, Organizacja i akta Chetmskiego Zarzadu Duchownego, s. 317-332; M. Kulik, Dokumentacja rosyjskich obiektów koszarowych na ziemiach polskich (przetom XIX i XX wieku), s. 343-352; W. Bagieński, Zaświadczenia wydawane mieszkańcom przez wtadze miasta Piaseczna pod Warszawa w latach 1916-1941, s. 489-503; A. G. Dąbrowski, Obieg pism w centrali Ministerstwa Spraw Wewnętrznych w latach 1918-1939, s. 527-543; R. Degen, Urzędnicy, selekcja i brakowanie dokumentacji w Polsce w XX w., s. 545-555; R. Galuba, Dostęp do informacji publicznej na podstawie ustawy z dnia 6 września 2001 roku o dostępie do informacji publicznej, s. 557-578; W. Berkowski, Biurokratyzacja systemu archiwalnego Ukrainy w latach 20. XX wieku, s. $579-586$.

History - Archive Studies - Information Science: Methodological Issues, ed. by K. Narojczyk, M. Świgoń, M. Wolny, Olsztyn 2010, Wydawnictwo Uniwersytetu Warmińsko-Mazurskiego, ss. 213

$\mathrm{Z}$ zakresu archiwistyki dwie prace: B. Ryszewski, Archive science in Poland, specifity, methodologial and theoretical foundations, s. 137-144; A. Żeglińska, On family and estate fonds. Selected problems, s. 145-153. 
Ksztatcenie archiwistów i zarządców dokumentacji. Model kompetencji zawodowych. Materiaty z konferencji Sekcji Edukacji Archiwalnej Stowarzyszenia Archiwistów Polskich, Instytutu Historii i Archiwistyki UMK i Towarzystwa Naukowego w Toruniu, Toruń, 2 grudnia 2009 r., red. W. Kwiatkowska, Poznań 2010, wyd. Stowarzyszenie Archiwistów Polskich, ss. 142

Piąty tom serii „Studia, Materiały, Konferencje Stowarzyszenia Archiwistów Polskich”.

W. Chorążyczewski, W. Kwiatkowska, Model kompetencji zawodowych archiwistów i zarządców dokumentacji. Wersja końcowa, s. 13-26; M. Karpińska, Pierwsze gtosy studentów w sprawie modelu ksztatcenia archiwistów wprowadzonego na UMK w Toruniu, s. 27-32; R. Kiper, Aktualne problemy zawodu archiwisty we Francji, s. 33-45; S. Ciara, A. Kulecka, Model warszawski w zakresie ksztatcenia archiwistów na studiach magisterskich, s. 47-53; ks. L. Wilczyński, Ksztatcenie archiwistów kościelnych w Polsce, s. 55-60; M. Wnuk, Podręczniki w akademickim nauczaniu archiwistyki, s. 61-96; A. Kulecka, Podręczniki archiwalne (pomiędzy teoriq a praktyka), s. 97-103; J. Tandecki, Nowy podręcznik edytorstwa źródet historycznych (koncepcja i plan), s. 105-114; I. Mamczak-Gadkowska, Refleksja na temat literatury do przedmiotu „Podstawy archiwistyki”, s. 115-120; W. Chorążyczewski, Projekt podręcznika „Archiwistyka dla początkujacych", s. 121-124; B. Kalinowska-Wójcik, Obóz naukowy jako uzupetniająca forma ksztatcenia studentów archiwistyki. Efekty pobytu studentów w „Bibliotece i Archiwum im. B. R. Tschammera" w Cieszynie, s. 125-136.

Ochrona informacji niejawnych, biznesowych $i$ danych osobowych. Materiaty VI Kongresu, red M. Gajos, Katowice 2010, wyd. Krajowe Stowarzyszenie Ochrony Informacji Niejawnych, Uniwersytet Śląski, ss. 251, 17 nlb., ilustr.

T. Brodzicki, Ochrona informacji niejawnych w jednostce samorzadowej, s. 29-34; S. Hoc, Geneza ustawy o ochronie informacji niejawnych, s. 34-56; L. F. Korzeniowski, Bezpieczeństwo informacyjne jako dobro spoteczne, s. 63-76; M. Krasińska, B. Pilc, M. Bałdyga, P. Drobek, A. Kaczmarek, Systemy monitoringu audiowizualnego jako systemy przetwarzające dane osobowe, s. 77-91; J. Krzykowska-Chmielewska, Ochrona danych osobowych a system zarzadzania bezpieczeństwem informacji wg normy PN-ISO/IEC 27001, s. 93-98; S. Małecki, Ochrona informacji niejawnych (zarys wystapienia podczas Kongresu), s. 133-139; B. Małota, Dziatania korygujace i zapobiegawcze w zintegrowanych systemach zarzadzania jakościq i bezpieczensstwem informacji, s.141-153; J. Porazinski, Problem ochrony informacji niejawnych $w$ archiwistyce i archiwach polskich. Zarys problemu, s. 155-164; G. Sibiga, Administrator bezpieczeństwa informacji (uwagi de lege lata), s. 165-172; P. Thiem, Wybrane zagadnienia bezpieczeństwa osobowego, s. 173-178; J. Trzęsimiech, Ochrona danych osobowych i informacji niejawnych $w$ ramach instytucji świadka koronnego, incognito i anonimowego, s. 179-193; 
Ł. Hoppe, T. Semeniuk, Ł. Wąsek, SWDOP. System Wspomagania Dziatań Operacyjno-Procesowych, s. 213-216; W. Paź, Opis Projektu Rozwojowego „Kancelarie Tajne”, s. 217-224.

Pamiętnik IX Ogólnopolskiego Zjazdu Studentów Archiwistyki. Archiwistyka wczoraj, dziś, jutro, Toruń 26-28.04.2006, red. M. Jabłońska, P. Ławniczak, Toruń 2010, ss. 232

Publikacja pokonferencyjna, w której ukazały się teksty wygłoszone przez młodych adeptów archiwistyki podczas IX Ogólnopolskiego Zjazdu Studentów Archiwistyki w Toruniu. Ponieważ archiwistyka była traktowana w szerokim ujęciu, hasłem spotkania stało się motto: „Archiwistyka wczoraj, dziś, jutro”. Publikowane artykuły poświęcone zostały m.in. problematyce źródłoznawstwa, archiwistyki, zarządzania dokumentacją.

K. Góral, D. Sitkiewicz, Archiwistyka polska \& Real-socjalizm. Diama, dialektyka marksistowsko-leninowska w polskojęzycznej literaturze archiwalnej. Zarys problemu, s. 54-63; B. Drzewiecki, Archiwum Diecezjalne we Wtoctawku - powstanie, funkcjonowanie, perspektywy, s. 64-73; R. Nowicki, Archiwum Komendy Choragwi Wielkopolskiej ZHP w Poznaniu, s. 74-80; A. Zielińska, Archiwa spoteczne czynu niepodlegtościowego jako organizacje pożytku publicznego. Struktura i organizacja na przyktadzie Fundacji „Archiwum i Muzeum Pomorskie Armii Krajowej" Toruniu, s. 81-91; P. Ciszewski, A. Paczuska, Polskie prawo archiwalne w XX wieku, s. 92-98; M. Małecka, Kancelaria tajna we wspótczesnym prawodawstwie polskim, s. 99-108; D. Mróz, Kancelaria Ministerstwa Kultury w latach 2001-2005, s. 109-117; P. Rumińska, Przyktadowy obieg pism we wspótczesnych instytucjach, s. 118-127; M. Jokiel, Państwowy nadzór archiwalny nad przedsiębiorstwami sprywatyzowanymi, s. 128-131; P. Ciara, I. Zwierzyńska, Podejście do udostępniania materiatów archiwalnych na przestrzeni XX wieku, s. 132-140.

W formie aneksu dołączony jest do publikacji program IX Ogólnopolskiego Zjazdu Studentów Archiwistyki.

\section{Public relations $w$ archiwach. Zbiór studiów, red. M. Jabłońska, Poznań 2010, wyd. Stowarzyszenie Archiwistów Polskich, ss. 176}

Czwarty tom serii „Studia, Materiały, Konferencje Stowarzyszenia Archiwistów Polskich”.

M. Jabłońska, Public relations w archiwach - wprowadzenie, s. 25-34; W. Stępniak, Promocja i popularyzacja dziatalności archiwów w pracach Międzynarodowej Rady Archiwów, s. 37-53; W. Chorążyczewski, Udziat stowarzyszeń archiwalnych $w$ budowie wizerunku archiwów, s. 55-62; I. Mamczak-Gadkowska, Dbatość o wizerunek archiwów polskich w 20-leciu mię- 
dzywojennym, s. 65-86; W. K. Roman, Polskie archiwa w mediach, s. 87-105; R. Arovelius, Public relations $w$ archiwach szwedzkich, s. 109-117; I. Buzaite, Public relations in Lithuanian archives: today's situation and perspective, s. 119-125; D. Joița, Doing PR for archives in Romania, s. 127-143; Z. Kollárová, Public relations archiwów państwowych w Stowacji, s. 145-150; H. Krajewska, Public relations $w$ archiwach $w$ Austrii i Niemczech, s. 151-160; M. Niedźwiedzka, Badanie wizerunku archiwów polskich - sonda uliczna, s. 169-172; A. J. Jastrzębowska, Przygody Pani B. Blondynka schodzi do archiwum, s. 173-176.

Rola nauki w zachowaniu dziedzictwa kulturowego. Wspótpraca między uczelniami wyższymi a muzeami, archiwami i stużbami konserwatorskimi na terenie regionu tódzkiego, red. B. Więcek, J. Perkowski, Łódź 2010, wyd. Wydawnictwo Politechniki Łódzkiej, ss. 189, ilustr.

Archiwistyki dotyczą dwa prezentowane w tomie artykuły: M. Sarwińska, Wspótczesne archiwa filmowe między cyfryzacja z zachowaniem dziedzictwa na przyktadzie dziatalności Archiwum Filmowego PWSFTViT w Łodzi, s. 115-124; M. Watanabe, Dziatalność Archiwum Państwowego w Łodzi w zakresie ochrony zasobu i zwiazane z tym problemy, s. 131-135.

Ryszard Przelaskowski: dyrektor, bibliotekarz, archiwista, Warszawa 2010, wyd. Biblioteka Publiczna m.st. Warszawy, Biblioteka Główna Województwa Mazowieckiego, ss. 128, ilustr.

Piękne edytorsko przypomnienie i uczczenie postaci wybitnego archiwisty i bibliotekarza, Ryszarda Przelaskowskiego (1903-1971), w 40. rocznicę jego śmierci.

Notatnik Ryszarda Przelaskowskiego, petniącego obowiązki dyrektora Biblioteki Publicznej m. Warszawy (maj 1940-wrzesień 1942), s. 8-38; Aneks zawierający fotokopie dokumentów z akt bibliotecznych z lat 1940-1942, s. 39-56; W. Guzek, Ryszard Przelaskowski (1903-1971), s. 57-68; Bibliografia publikacji o Ryszardzie Przelaskowskim, s. 69; fotokopie dokumentów osobistych i fotografii Ryszarda Przelaskowskiego, s. 70-78; W. Chorążyczewski, Myśl archiwalna Ryszarda Przelaskowskiego (1903-1971), s. 79-112; Bibliografia prac Ryszarda Przelaskowskiego, s. 113-122; fotokopia zapisków Ryszarda Przelaskowskiego z roku 1949, s. $126-128$.

Urzędy państwowe, organy samorządowe $i$ kościelne oraz ich kancelarie na polsko-ruskim pograniczu kulturowym $i$ etnicznym $w$ okresie od $X V$ do XIX wieku. Materiaty polsko-ukrainskiej konferencji w Okunince koto 


\section{Wtodawy 10-12 września 2007 roku, red. H. Gmiterek, J. Losowski, Kra- ków 2010, wyd. Avalon, ss. 830, 1 nlb., ilustr. do książki na osobnej wkładce}

Tom dzieli się na dwie części. Pierwsza jest zatytułowana Urzędy, instytucje i organy samorządowe, a druga Kancelarie. Ta druga część bardziej nas interesuje. Kluczem do zrozumienia książki jako całości jest kategoria pogranicza: etnicznego, religijnego, kulturowego, głównie polsko-ruskiego, ale z udziałem Ormian, Żydów czy Rosjan. Wyczula to na szczególne problemy z krytyką źródeł, na analizę przenikania się wzorców kulturowych i prawnych na samym dole struktur społecznych. Trzeba jednak rozumieć, że materiały konferencyjne nigdy nie mają szansy na metodologiczną spójność. W niektórych artykułach brak wyraźnie związku z problematyką pogranicza, w innych ten związek jest silny. Wszystkie jednak teksty mają dużą wartość poznawczą same w sobie. Jako całość, jako zbiór studiów, omawiane materiały pokazują przenikanie się kulturowe społeczności zamieszkujących polsko-ruskie pogranicze od późnego średniowiecza po początek XX w., upodabnianie się instytucji prawnych i zwyczajów kancelaryjnych dzięki długotrwałemu współżyciu, wytwarzanie się swoistej i odrębnej kultury pogranicza.

A. Łosowska, Kancelaria biskupa przemyskiego Jana z Targowisk (1486-1492), s. 439-472;

B. Petriszak, Miśki pisari Lwowa XV st.: prosopograficzne doslidżennia, s. 473-500; M. Kulecki, Akta sadów ziemskich i grodzkich podlaskich przed inkorporacja Podlasia do Korony, s. 501-509; Mikoła Ilkiw-Swidnickij, Kanceliarija lwiwskogo magistratu kinca XIV-XVI st. jak kulturnij oseredok, s. 511-533; A. Grecziło, Miski peczatki Lwowa XIV-XVIII st., s. 535-550; M. Kapral, Nawczannia remestu u Lwowi w ranniomodernij period: uczni ta pidmajstri za statutami remisniczich cechiw, s. 551-573; K. Madejska, Ekstrakty w praktyce kancelaryjnej matych miast królewskich województwa lubelskiego, s. 575-597; J. Łosowski, Kancelaria na pograniczu etnicznym i kulturowym na przyktadzie sqdu ormiańskiego $w$ Zamościu $w$ XVII wieku, s. 599-633; O. Winniczenko, Szlachetśki testamenti w kanceliarii (na materiatach lwiwskich ta peremyszlskich rodskich aktiw perszoj potowini XVIII stolittia), s. 635-655; Witold Bobryk, Kancelerie parafialne w unickiej diecezji chetmskiej w XVIII wieku, s. 657-668; O. Karlina, Magistrat Wotodimira-Wotinśkogo w perszoj potowini XIX st.: sktad, pownoważennia, dokumentacija, s. 669-690; J. Glistiuk, Dokumentacija Generalnoj greko-katolićkoj duchownoj seminarii u Lwowi (1848-1914), s. 691-699; A. Górak, Organizacja i kancelaria zarzadów powiatowych $w$ Królestwie Polskim $w$ latach 1867-1918, s. 701-766; K. Latawiec, Chetmski Zarzad Duchowny, jego kancelaria oraz personel w latach 1876-1905, s. 767-812; M. Śliź, Żydowskie urzędy metrykalne i ich kancelarie $w$ Galicji w świetle rozporzadzenia z dnia 15 marca 1875 roku, s. 813-826; O. Duch, Kronika jaworowskiego monasteru bazylianek i jej autorki, s. 827-831. 
Wystapienia wygtoszone podczas konferencji: „Przesztość dla Przysztości. Masowe zabezpieczanie zasobów bibliotek i archiwaliów, Kraków 13-14.10. 2008”, red. T. Łojewski, Kraków 2010, wyd. Biblioteka Jagiellońska, ss. 320, ilustr.

Podczas konferencji zaprezentowano efekty kończącego się Wieloletniego Programu Rządowego na lata 2000-2008 „Kwaśny papier. Ratowanie w skali masowej zagrożonych polskich zasobów bibliotecznych i archiwalnych" w Polsce na tle osiągnięć w innych krajach w dziedzinie zabezpieczania zbiorów bibliotecznych, archiwalnych i muzealnych. Prezentowane artykuły są zaopatrzone bądź w anglojęzyczne abstrakty, bądź są całkowicie przetłumaczone na język angielski. Archiwistyki dotyczy osiem prezentowanych w tomie tekstów.

A. Czajka, Masowa konserwacja i reprografia. Dwie drogi ratowania archiwaliów z XIX i XX wieku $w$ archiwach państwowych, s. 31-38; J. Hanus, M. Bajzikowá, V. Bukowský, E. Halusová, Ochrona dziedzictwa narodowego w archiwach i bibliotekach Republiki Stowackiej, s. 55-74; M. Durovič, B. Havlínová, H. Paulusom, R. Straka, Masowe odkwaszanie w archiwach. Porównianie metod Bookkeeper i CSC Book Saver, s. 151-175; T. Kozielec, Przed, w czasie i po odkwaszaniu. Co dalej? Kilka uwag na temat wtaściwości odkwaszonych materiatów archiwalnych i bibliotecznych na wybranych przyktadach, s. 179-195; D. Maxwell, Masowe odkwaszanie w Bibliotece i Archiwach Kanady. Dziatalność wtasna i ustugi zewnętrzne-porównanie, s. 207-219; A. Czajka, Konserwacja masowa $w$ archiwach i bibliotekach - różnice i podobieństwa. Uwagi na zakończenie WPR „Kwaśny papier”, s. 221-228; A. A. Endress, Masowe odkwaszanie zbiorów Gtównego Archiwum Państwowego Nadrenii Pótnocnej-Westfalii w Niemczach, s. 229-238; T. Sawoszczuk, T. Łojewski, Mikroklimat pudet archiwalnych, s. 295-301 (poster).

Z badań nad dziejami kancelarii i opracowania akt austriackich z XVIII-XX wieku na ziemiach polskich. Wyniki prac zespotu naukowego powotanego przez Naczelnego Dyrektora Archiwów Państwowych do przygotowania wskazówek metodycznych pomocnych przy opracowaniu akt wytworzonych w okresie funkcjonowania kancelarii austriackiej, red. i wstęp J. Gaul, Warszawa 2010, wyd. Naczelna Dyrekcja Archiwów Państwowych, ss. 130

J. Gaul, Z badań nad wojskowa kancelaria austriacka w Galicji i Królestwie Polskim 1772-1918, s. 13-42; J. Szyposz, Metody porzadkowania akt kancelarii austriackiej w Archiwum Państwowym w Krakowie, s. 43-58; M. Dalecki, Metody opracowania akt kancelarii austriackiej w Archiwum Państwowym w Przemyślu, s. 59-82; P. Hudzik, Ogólny przegląd zespotów austriackich przechowywanych $w$ archiwach państwowych w Polsce, s. 83-109; Projekt wskazówek metodycznych pomocnych przy opracowaniu akt wytworzonych $w$ okresie funkcjonowania kancelarii austriackiej, s. 111-128. 
Zbiory biblioteczne, muzealne i archiwalne - badania i konserwacja. Materiaty z konferencji zorganizowanej przez Zaktad Konserwacji Papieru i Skóry UMK, Toruń, 2-4 października 2008 roku, red. E. Jabłońska, Toruń 2010, wyd. Wydawnictwo Naukowe UMK, ss. 274, 1 nlb., ilustr.

Tom dedykowany profesor Alicji Strzelczyk-Brąszkiewicz, twórczyni toruńskiej szkoły konserwacji papieru i skóry. Cały zbiór powinien zainteresować konserwatorów archiwaliów. W szczególniejszy sposób archiwaliów dotyczy pięć artykułów.

V. Bachur, Archiwum Ringelbluma - z zagadnień konserwacji zespotu podziemnego archiwum getta warszawskiego, s. 91-100; M. Trojan-Bedyńska, S. Guild, S. Tse, Kanadyjski program ochrony zbiorów rękopiśmiennych zawierających atramenty żelazowo-galusowe, s. 111-128; L. Bannach-Szewczyk, B. Wojdyła, Konserwacja wielkoformatowych kolorowych planów rękopiśmiennych, s. 149-160; J. Karbowska-Berent, T. Kozielec, J. Jarmiłko, B. Brycki, Próby zastosowania nowych preparatów biobójczych do dezynfekcji zabytkowego papieru, s. 183-197; E. Jabłońska, Problematyka konserwacji-restauracji zabytkowych obiektów z wosku, s. 221-232.

\section{WSPÓŁCZESNA BIUROWOŚĆ}

Beata Bal-Domańska, Aneta Salus, Wstęp do e-administracji. E-obieg dokumentów w administracji publicznej z wykorzystaniem el-Dok-Systemu, Wrocław 2010, wyd. Wydawnictwo Uniwersytetu Ekonomicznego we Wrocławiu, ss. 80, 4 nlb., ilustr.

Skrypt przeznaczony dla studentów kierunków administracja oraz ekonomia i zarządzanie. W pierwszym rozdziale zostały pomieszczone rozważania nad pojęciem i historią e-administracji. Drugi rozdział to prezentacja konkretnego rozwiązania informatycznego, elektronicznego systemu obiegu dokumentów el-Dok System.

Dokumentacja kadrowa w oświacie - 25 praktycznych wskazówek, red. A. Rumik, Warszawa 2010, wyd. Wydawnictwo Wiedza i Praktyka, ss. 39

Celem autorów było przekazanie informacji, które pozwolą wyeliminować najbardziej istotne lub najczęstsze błędy w prowadzeniu akt osobowych. 
Bożena Fronckiewicz, Jolanta Kołodziejska, Organizowanie i dokumentowanie pracy $w$ szkole podstawowej. Praktyczne rozwiąania, Warszawa, ABC a Wolters Kluwer Business, 2010, ss. 153 (dołączona płyta CD „Wzory do edycji”)

Publikacja powstała jako inicjatywa mająca wesprzeć dyrektorów szkół realizujących zadania wynikające z nowej podstawy programowej z 2009 r. Jest to poradnik metodyczny pokazujący, jak tworzyć dokumentację w szkole. W związku ze zmianą podstawy programowej pojawiły się w codziennej pracy dyrektorów szkół problemy z dostosowaniem prowadzonej dokumentacji do nowych wymagań programowych, a także z tworzeniem stosownie do potrzeb nowej dokumentacji. Opracowanie jest zaopatrzone we wzory poprawnie zbudowanych pism, np. statut szkoły, regulamin organów szkoły, dokumentacja dyrektora szkoły, dokumentacja dotycząca organizacji roku szkolnego, dokumentacja przebiegu nauczania i obowiązku szkolnego itp.

Dorota Hołubiec, Zarządzanie kancelaria prawna. 100 najważniejszych pytań, jak to robićskutecznie, Warszawa 2010, wyd. Wolters Kluwer Polska Sp. z o.o., ss. 326

Poradnik napisany z myślą o organizacji kancelarii i prawnych. W pracy między innymi odpowiedzi na pytania o narzędzia informatyczne wspomagające zarządzanie kancelarią, jak zapewnić poufność danych i informacji klienta, jak zarządzać jego dokumentacją.

Radosław Jaworski, Oprogramowanie biurowe, Warszawa 2010, wyd. Wydawnictwa Szkolne i Pedagogiczne, ss. 329, 3 nlb., ilustr.

Trzecie wydanie podręcznika prezentującego podstawowe wiadomości na temat posługiwania się programami komputerowymi przydatnymi w pracy biurowej. Podręcznik jest przeznaczony do nauki przedmiotu „Oprogramowanie biurowe” zgodnie z programem nauczania w zawodzie technik informatyk. 
Andrzej Komosa, Praca biurowa, cz. 2: Zasady korespondencji. Profesjonalny pracownik w biurze. Organizacja pracy w sekretariacie, Warszawa 2010, wyd. Ekonomik s.c., ss. 139, ilustr.

Podręcznik przeznaczony dla uczniów liceum profilowanego, profil ekonomiczno-administracyjny. Wydano do niego osobno zbiór ćwiczeń (A. Komosa, Praca biurowa, cz. 2: Ćwiczenia, Warszawa 2010, wyd. Ekonomik s.c., ss. 91).

Mariusz Luterek, e-government. Systemy informacji publicznej, Warszawa 2010, wyd. Wydawnictwa Akademickie i Profesjonalne, ss. 197

Studium poświęcone organizacji systemu e-government jako zbiorowi informacji. Autor kolejno przedstawił miejsce administracji publicznej w społeczeństwie informacyjnym, organizację systemów e-government w wybranych krajach, systemy informacji publicznej w Stanach Zjednoczonych i Unii Europejskiej oraz organizacje systemu informacji publicznej w Polsce.

Dorota Michalak, Dokumentacja w pracy nauczyciela publicznej szkoty i przedszkola, Warszawa 2010, wyd. Zarząd Główny Związku Nauczycielstwa Polskiego, ss. 47

Praca prezentuje uprawnienia i ustawowe obowiązki nauczycieli w zakresie tworzenia i dostępu do dokumentacji szkolnej. Umieszcza tę problematykę w kontekście obowiązków dydaktycznych, wychowawczych i opiekuńczych nauczycieli, charakteryzując w prosty sposób mechanizmy wytwarzania dokumentacji w publicznych szkołach i przedszkolach.

Józef Władysław Michniak, Teleinformatyka i technika biurowa, Warszawa 2010, wyd. Akademia Obrony Narodowej, ss. 184, 1 nlb., ilustr.

Opracowanie, napisane przede wszystkim z myślą o studentach Akademii Obrony Narodowej, ma wspierać kształcenie w ramach przedmiotu „Teleinformatyka i technika biurowa" realizowanego na kierunku zarządzanie i dowodzenie. Poza uwagami natury ogólnej, odnoszącymi się do istoty telekomunikacji i teleinformatyki, zawiera przegląd i charakterystykę urządzeń kancelaryjno-biurowych oraz środków i systemów teleinformatycznych wykorzystywanych przez polskie siły zbrojne. 
Eugeniusz Woźniak, Przyktadowa instrukcja kancelaryjna wraz z rzeczowym wykazem akt w jednostkach organizacyjnych oświaty, pomocy spotecznej $i$ in., Gliwice 2010, wyd. Novator. Ośrodek Szkoleniowo-Doradczy, ss. 157

Treść opracowania odzwierciedla stan prawny na 15 października 2010 r. Poza wymienionymi w tytule instrukcją kancelaryjną i rzeczowym wykazem akt, zawiera także krótki zarys zasad archiwizacji dokumentacji. Wśród załączników m.in. wyciąg z instrukcji kancelaryjnej dla gmin i związków międzygminnych z 1999 r., opis trybu postępowania podczas brakowania dokumentacji niearchiwalnej.

Halina Robótka, Wspótczesna biurowość. Zagadnienia wstępne, Toruń 2010, wyd. Wydawnictwo Naukowe UMK, ss. 167

Praca odnosi się do podstawowych problemów związanych z funkcjonowaniem współczesnych kancelarii. W kilku rozdziałach niewielkiej objętości autorka przybliżyła definicje i znaczenie terminu „kancelaria”, scharakteryzowała dawne i współczesne instrukcje kancelaryjne, poruszyła problematykę wykazów akt i standardów, jakie muszą one dziś spełniać, opisała zasady pracy $\mathrm{w}$ scentralizowanych i zdecentralizowanych kancelariach oraz zdefiniowała podstawowe terminy z zakresu zarządzania dokumentacją. Istotnym uzupełnieniem są aneksy, w których pojawiły się przedruki najważniejszych dla zarządzania dokumentacją przepisów prawnych i metodycznych. Zeszyt otwierający serię wydawniczą „Biblioteczka Zarządcy Dokumentacji”.

\section{Katalogi wystaw}

... A akta zniszczyć. Archiwa komunistycznego aparatu represji w Polsce $i$ innych krajach Europy. Katalog wystawy, Warszawa 2010, wyd. Instytut Pamięci Narodowej - Komisja Ścigania Zbrodni przeciwko Narodowi Polskiemu, Biuro Udostępniania i Archiwizacji Dokumentów, ss. 103, 1 nlb., ilustr.

Katalog wystawy zorganizowanej w październiku 2010 r. i prezentowanej na Placu Zamkowym w Warszawie. Wydawnictwo dwujęzyczne. Jego tytuł w języku angielskim: ... And the files to be destroyed. Archives of the communist repressive apparatus in Poland and other European countries. 
Adam Dudek, Ryszard Kaczmarek, Mirosław Węcki, „Dobro publiczne mieć zawsze przed oczyma...” Policja Województwa Śląskiego 1922-1939. Katalog wystawy Archiwum Państwowego w Katowicach, Katowice 2010, wyd. Archiwum Państwowe w Katowicach, ss. 72, ilustr.

Katalog wystawy przygotowanej we wrześniu 2010 r. przez Archiwum Państwowe w Katowicach przy współpracy z Komendą Wojewódzką Policji w Katowicach. Publikacja zaopatrzona w trójjęzyczny wstęp (polski, niemiecki, angielski) ma też trzy tematyczne teksty autorstwa znawców dziejów policji województwa śląskiego (Janusza Mikitina, Adama Momota, Grzegorza Grześkowiaka). W katalogu jest zawarty wybór zdjęć i dokumentów eksponowanych na wystawie, przedstawiających najważniejsze wydarzenia ze służby i życia codziennego funkcjonariuszy policji województwa śląskiego: jej struktura i obsada kadrowa, przebieg służby, umundurowanie, uzbrojenie, szkolenie, metody działania, sposoby spędzania wolnego czasu. Całość eksponatów zaprezentowanych na wystawie została podzielona na kilka części: początki PWŚL, komendy, komendanci, na służbie, szkolenie, kryminalistyka, mundur, uzbrojenie, wyposażenie, w akcji, polityka, na paradzie, rodzina policyjna, po służbie, sport, wrzesień '39, w niewoli. Prezentowane w katalogu obiekty nie zostały niestety opisane - nie wskazano, z jakich pochodzą zbiorów lub zespołów archiwalnych.

„Gdańsk miastem wielu kultur - powrót do korzeni. Katalog wystawy”, oprac. A. Biedziak, M. Kurr, L. Potykanowicz-Suda, J. Strehlau, Gdańsk 2010, wyd. Urząd Miejski w Gdańsku, Biuro Prezydenta ds. Kultury, ss. 60, ilustr.

W ramach III Światowego Zjazdu Gdańszczan (odbywającego się w dniach 21-23 maja 2010 r.) Archiwum Państwowe w Gdańsku przygotowało wystawę pt.: „Gdańsk miastem wielu kultur - powrót do korzeni”. Na ekspozycji zostały zaprezentowane wybrane archiwalia obrazujące wielokulturowość Gdańska na przestrzeni wieków, ze szczególnym uwzględnieniem materiałów do badań genealogicznych. Eksponaty zostały opisane w katalogu wydanym w trzech wersjach językowych, który jest rezultatem współpracy Archiwum Państwowego w Gdańsku z Urzędem Miejskim w Gdańsku oraz Biurem Prezydenta ds. Kultury. Poza szczegółowym opisem archiwaliów prezentowanych na wystawie (70 pozycji) katalog zawiera 38 kolorowych reprodukcji w układzie chronologicznym. 
Grunwald. 600 lat chwaty. Katalog wystawy, oprac. J. Grabowski, Warszawa 2010, wyd. Archiwum Główne Akt Dawnych, Stowarzyszenie Miłośników Dawnych Dokumentów „Archivum Patriae”, ss. 167, ilustr.

Wystawa „Grunwald - 600 lat chwały” została przygotowana przez Archiwum Główne Akt Dawnych w Warszawie i Stowarzyszenie Miłośników Dawnych Dokumentów „Archivum Patriae”. Słowo wprowadzające napisał Hubert Wajs, dyrektor AGAD. Stosunki Polski z zakonem krzyżackim w XIII-XVI w. scharakteryzował obszernie Janusz Grabowski. Publikacja zawiera liczne kolorowe mapy, znakomitej jakości barwne fotokopie pieczęci, dokumentów pergaminowych i papierowych, fragmentów „Banderia Prutenorum”, Metryki Koronnej i innych ksiąg.

I Warszawa nie zawiodta. W 90. rocznice bitwy warszawskiej, Warszawa 2010, wyd. Archiwum Państwowe m.st. Warszawy, Naczelna Dyrekcja Archiwów Państwowych, ss. 83, ilustr.

Wystawa, która prezentuje najważniejsze wydarzenia wojny z Rosją bolszewicką oraz wysiłek całego narodu w walce o niepodległość Polski, przede wszystkim jednak ukazuje walki na przedmieściu stolicy oraz rolę Warszawy i jej mieszkańców, „którzy jako żołnierze brali udział w bitwie, a także w inny sposób wspierali walczących na froncie, o czym opowiada autor ekspozycji dr Andrzej Stawarz", została zorganizowana w 90. rocznicę bitwy warszawskiej. $\mathrm{Na}$ wystawie zaprezentowano materiały pochodzące z zasobu kilku instytucji: m.in. Narodowego Archiwum Cyfrowego, Archiwum Państwowego m.st. Warszawy, Archiwum Państwowego w Krakowie, Archiwum Państwowego w Łodzi, Instytutu Józefa Piłsudskiego w Ameryce, Muzeum Wojska Polskiego, Centralnego Archiwum Wojskowego, Muzeum Niepodległości, ale także materiały będące efektem odpowiedzi mieszkańców Warszawy i Mazowsza na ogłoszony przez AP m.st. Warszawy apel o przekazywanie dokumentów związanych z bitwą. Prezentowane w przewodniku eksponaty nie są niestety wyposażone w odpowiednie opisy, oprócz tytułów pod ilustracjami i tekstów narracyjnych brak jest informacji o miejscu ich przechowywania/pochodzenia.

Kazimierz stawny i z czynów wielki. Przewodnik po wystawie, Zamek ksiażąt Lubomirskich w Nowym Wiśniczu, maj-sierpień 2010, oprac. Z. Czekalska-Sitko, A. Gicala, J. Potasz, Kraków 2010, wyd. Archiwum Państwo- 
we w Krakowie, Instytut Historii Uniwersytetu Jagiellońskiego, ss. 47, ilustr.

Na wystawie prezentowanej w Zamku książąt Lubomirskich w Nowym Wiśniczu zaprezentowano 34 eksponaty - dokumenty (także pergaminy i pieczęcie) przeplatane materiałami ikonograficznymi, dzięki którym autorki (pracownice Oddziału w Bochni Archiwum Państwowego w Krakowie), ukazały czasy panowania Kazimierza Wielkiego. Wystawa, jak podaje w dwujęzycznym wstępie (polski i angielski) Zofia Czekalska-Sitko, została skierowana do szerokiej publiczności, ale głównie młodzieży szkolnej. Obiekty pochodzą ze zbiorów: Archiwum Państwowego w Krakowie, Archiwum Głównego Akt Dawnych, Archiwum Uniwersytetu Jagiellońskiego w Krakowie, Muzeum Narodowego w Krakowie, Muzeum Żup Krakowskich w Wieliczce, Opactwa Ojców Cystersów w Mogile, Sanktuarium Świętego Józefa w Kaliszu, Urzędów Miast i Gmin w Bochni, Niepołomicach, Radomiu, Skawinie, Sandomierzu, Wieliczce i Wiśnicy. Wystawa została podzielona na cztery działy zaopatrzone w komentarze zaczerpnięte $\mathrm{z}$ wydawnictw źródłowych opisujących czasy panowania króla - przede wszystkim z Roczników Jana Długosza: Rodowód Kazimierza Wielkiego, Kazimierz jako król Polski, Kazimierz król zakłada na Kazimierzu wszechnicę naukową, Polityka dynastyczna Kazimierza Wielkiego. Każdy z prezentowanych eksponatów jest zaopatrzony w stosowną charakterystykę obejmującą: dwujęzyczny opis eksponatu (tytuł), miejsce przechowywania: instytucja, zespół/zbiór, sygnatura (czasem też dawna sygnatura). Kuratorem wystawy była Joanna Potasz.

Landsberg an der Warthe. Zwei Namen - eine Geschichte. Gorzów Wielkopolski. Jedno miasto - wspólna historia. Katalog wystawy, oprac. F. Neininger, J. Sikorski, Gorzów Wielkopolski 2010, wyd. Archiwum Państwowe w Gorzowie Wielkopolskim, Brandenburskie Główne Archiwum Krajowe w Poczdamie, ss. 263, ilustr.

Katalog wystawy zorganizowanej wspólnie przez Archiwum Państwowe w Gorzowie Wielkopolskim i Brandenburskie Główne Archiwum Krajowe w Poczdamie z okazji 60. rocznicy utworzenia Archiwum Państwowego w Gorzowie Wielkopolskim. Wystawa stanowiła efekt kilkuletniej współpracy obu tych placówek, mającej na celu poznanie zasobu archiwum brandenburskiego w odniesieniu do obszaru działania gorzowskiego archiwum. Jest to pierwszy projekt realizowany na ziemi lubuskiej, w którym archiwa niemieckie i polskie prezentują wspólnie zasób archiwalny dotyczący przeszło- 
ści tego obszaru, a w szczególności Gorzowa Wielkopolskiego. Rezultaty tej współpracy zostały upublicznione w postaci prezentowanej wystawy, która została podzielona na 20 działów tematycznych, odpowiadających różnym aspektom istnienia miasta i regionu lubuskiego, m.in. religie i kościoły, handel i komunikacja, rzemiosło, szkolnictwo, przemysł, kultura i sport, gmina żydowska itp. Każdy dział wystawy jest zaopatrzony w zwięzły opis historyczny, a każdy z prezentowanych dokumentów jest właściwie opisany, krótko scharakteryzowano też jego treść w języku polskim i niemieckim, a także wskazano miejsce jego przechowywania.

„750 lat Tczewa w archiwaliach”, red. L. Potykanowicz-Suda, Pelplin 2010, wyd. Wydawnictwo „Bernardinum”, ss. 104, ilustr.

Katalog ekspozycji przygotowanej we współpracy Archiwum Państwowego w Gdańsku, Fabryki Sztuk - Centrum Wystawienniczo-Regionalnego Dolnej Wisły w Tczewie oraz Zrzeszenia Kaszubsko-Pomorskiego. Wystawa przedstawiała archiwalia z zasobu gdańskiego archiwum, wśród nich: źródła pisane, mapy, wycinki gazet oraz dokumenty portretujące historię miasta Tczewa. Katalog zawiera opracowanie dr Anieli Przywuskiej prezentujące „Źródła do dziejów miasta Tczewa w zasobie archiwum Państwowego w Gdańsku".

Polacy w Gruzji. Poles in Georgia, oprac. A. Zadrożniak, M. Filina, W. Materski, Warszawa 2010, wyd. Naczelna Dyrekcja Archiwów Państwowych, Archiwum Państwowe m.st. Warszawy, ss. 83, ilustr.

Katalog wystawy poświęconej Polakom w Gruzji jest pokłosiem wspólnego projektu Naczelnej Dyrekcji Archiwów Państwowych i Archiwum Narodowego Gruzji. Jest to wydawnictwo dwujęzyczne (język polski i angielski). Ekspozycja przygotowana przez Archiwum Państwowe m.st. Warszawy została otwarta w 90. rocznicę nawiązania przez Polskę i Gruzję współpracy politycznej i wojskowej. Autorką scenariusza wystawy jest Aleksandra Zadrożniak, merytoryczne opracowanie przygotowali: Aleksandra Zadrożniak, prof. Maria Filina i prof. Wojciech Materski. Celem wystawy, jak to określił dyrektor AP m.st. Warszawy Ryszard Wojtkowski, było przedstawienie Polaków mieszkających w Gruzji w XIX i XX w., ich wkładu w rozwój gospodarczy i kulturalny kraju oraz działalność polskich organizacji społeczno-kulturalnych. $\mathrm{Na}$ ekspozycji zaprezentowano materiały archiwalne pochodzące 
z zasobu Archiwum Narodowego Gruzji i Gruzińskiego Narodowego Muzeum Sztuki im. Szałwy Amiranaszwilego, które uzupełniono dokumentami z polskich placówek: Archiwum Głównego Akt Dawnych i Archiwum Akt Nowych oraz fotografiami (gł. prywatnymi) obrazującymi współczesną Gruzję. Wydawnictwo jest zaopatrzone we wstęp autorstwa prof. Marii Filiny na temat obecności Polaków w Gruzji. Katalog został podzielony chronologicznie i rzeczowo na 15 działów. Wszystkie prezentowane dokumenty zostały odpowiednio opisane, wskazano też archiwa, w których są przechowywane, brakuje natomiast informacji o dokładnym miejscu ich przechowywania w strukturze zasobów poszczególnych archiwów (zespół, sygnatura).

Stolica Prymasów. Katalog wystawy zorganizowanej przy wspótudziale Muzeum Archidiecezji Gnieźnieńskiej i Archiwum Archidiecezjalnego w Gnieźnie, red. S. Paściel, Gniezno 2010, wyd. Muzeum Początków Państwa Polskiego, ss. 686

Wystawa została zorganizowana z okazji powrotu tytułu Prymasa Polski do Gniezna. Publikacja zawiera katalog wystawy, a także trzy eseje poruszające problematykę metropolii gnieźnieńskiej i prymasostwa od XI do XX w. Scenariusz i koncepcja ekspozycji zostały opracowane przez Stanisława Paściela, jej komisarzem był Jakub Marian. W publikacji jest zamieszczony spis katalogowy prezentowanych na wystawie eksponatów. Wystawa została podzielona chronologicznie na cztery części: Metropolia gnieźnieńska 1000 r.-pocz. XV w., Prymasi schyłku średniowiecza i doby odrodzenia, Prymasi doby baroku, Arcybiskupi gnieźnieńscy. Prezentowane eksponaty pochodziły z polskich zbiorów państwowych i kościelnych, m.in. z Archiwum Archidiecezjalnego w Gnieźnie, Archiwum Archidiecezjalnego w Pelplinie, Archiwum Państwowego w Poznaniu i Archiwum Państwowego w Bydgoszczy.

Ta ostatnia dekada... Radom i region radomski w latach 80. XX wieku. Katalog wystawy, oprac. A. Jankowska, A. Kutkowski, Lublin-Radom 2010, wyd. Archiwum Państwowe w Radomiu, Instytut Pamięci Narodowej - Komisja Ścigania Zbrodni przeciwko Narodowi Polskiemu, Oddziałowe Biuro Edukacji Publicznej w Lublinie, Delegatura w Radomiu, ss. 111, ilustr.

Scenariusz wystawy i katalog opracowały Anna Jankowska i Arkadiusz Kutkowski. Prezentowane eksponaty pochodzą ze zbiorów Archiwum Państwowego w Radomiu oraz Instytutu Pamięci Narodowej - Delegatury w Ra- 
domiu. Wystawa została podzielona na dziewięć działów tematycznych, wydzielonych chronologicznie, począwszy od narodzin „Solidarności”, aż po czas przemian ustrojowych na przełomie lat osiemdziesiątych i dziewięćdziesiątych. Na wystawie zostały zaprezentowane nie tylko dokumenty archiwalne, ale także fotografie, wycinki z gazet i in., mimo jednak pięknej szaty graficznej w publikacji brakuje podstawowych opisów eksponatów (instytucja, zespół/zbiór, sygnatura itp.).

\section{MONOGRAFIE I PODRĘCZNIKI}

Tomasz Czarnota, To zawsze zostanie dla potomności... Archiwalia w kręgu myśli i prac Jerzego Giedroycia, Lublin 2010, wyd. Wydawnictwo Uniwersytetu Marii Curie-Skłodowskiej, ss. 525

Książka prezentuje koncepcje i działania Jerzego Giedroycia podejmowane wobec własnej oraz cudzej dokumentacji. Jak to autor publikacji sam określił: „Na tle półwiecznej działalności Instytutu Literackiego ukazuje ona m.in. procesy kształtowania się archiwum oficyny oraz zagadnienia przechowywania, porządkowania i udostępniania jego zasobu. Opisuje ponadto zaangażowanie redaktora "Kultury» w zapewnienie polskim zbiorom znajdującym się w kraju, a zwłaszcza poza jego granicami należytego bezpieczeństwa, właściwego rozmieszczenia, opracowania i dostępności”. Poszczególne rozdziały zostały poświęcone zagadnieniom systemu pracy biurowej J. Giedroycia, gromadzeniu dokumentacji, przechowywaniu i deponowaniu, porządkowaniu oraz udostępnianiu archiwaliów, poglądom i działaniom J. Giedroycia związanym z innymi archiwami. Praca jest zaopatrzona w aneksy - kopie dokumentów z Archiwum Instytutu Literackiego.

Piotr Dudzikowski, O profilaktyce i zabezpieczaniu materiatów archiwalnych czyli Elementarz, poradnik i przewodnik dla renowatorów, bibliotekarzy $i$ archiwistów, Warszawa-Mysłowice 2010, wyd. Wydawnictwo Naukowo-Techniczne, Median Polska, ss. 85, 3 nlb., ilustr.

Książka została opublikowana przez Wydawnictwo Naukowo-Techniczne w 2010 r. Jej autorem jest Piotr Dudzikowski - absolwent Katolickiego Uniwersytetu Lubelskiego na kierunku historia sztuki oraz członek Stowarzyszenia Archiwistów Polskich. Książka składa się z sześciu rozdziałów poświęconych kolejno budowie i przyczynom starzenia materiałów tworzących 
dokument archiwalny, czyli papierowi i atramentowi (rozdz. 1 i 2), prawidłowemu projektowaniu pomieszczeń magazynowych w archiwach (rozdz. 3), czynnikom niszczącym papier (rozdz. 4), profilaktyce i zabezpieczeniu materiałów archiwalnych (rozdz. 5) i odkwaszaniu (rozdz. 6).

Ewa Grin-Piszczek, Wanda Kaput, Przemyśl 2010, wyd. Archiwum Państwowe w Przemyślu, ss. 35, ilustr.

Opracowanie wydane z okazji 135-lecia istnienia Archiwum Miejskiego oraz 60-lecia powstania Archiwum Państwowego w Przemyślu jest poświęcone Wandzie Kaput, wieloletniej archiwistce Archiwum Państwowego w Przemyślu (od 1953 r.), a następnie Archiwum Państwowego w Krakowie (od 1972 r.), zmarłej w 2004 r.

Halina Robótka, Opracowanie i opis archiwaliów. Podręcznik akademicki, Toruń 2010, wyd. Wydawnictwo Naukowe UMK, ss. 325

Książka składa się z czterech części. W pierwszej (Zagadnienia ogólne) autorka omawia elementy rozpoznawcze archiwaliów i metodę opracowania zespołu archiwalnego. Część druga została poświęcona opracowaniu tradycyjnemu, w kolejnych rozdziałach są opisywane: studia wstępne, wyodrębnianie zespołu archiwalnego, brakowanie, porządkowanie, inwentaryzacja, opracowanie innych pomocy archiwalnych, a wreszcie tradycyjny system informacji archiwalnej. W części trzeciej (Opracowanie komputerowe) autorka dokonuje przeglądu dziejów komputeryzacji archiwów, standardów archiwalnego opisu informacyjnego, omawia informatyczny system informacji $\mathrm{w}$ archiwach, projektuje informatyczny system obsługi archiwum. Część czwarta to słownik terminologiczny, w jaki bywają wyposażone podręczniki, czyli właściwie już nie aneks. Nie wiedzieć czemu, autorka odróżnia załączniki od aneksów, wprowadzając tak zwane przez siebie załączniki w tekst, czyniąc je tym samym zwykłymi ilustracjami. Aneksy zawierają kilka powszechnie znanych i dostępnych przepisów metodycznych.

Krzysztof Syta, Archiwa magnackie w XVIII wieku. Studium kultury kancelaryjno-archiwalnej, Toruń 2010, ss. 312

Jest to pierwsza próba całościowego ujęcia zjawiska archiwów magnackich, ciekawe studium monograficzne, które sumuje i rozszerza dotychczasową 
wiedzę. Odtąd każdy piszący o staropolskich archiwach prywatnych będzie musiał odnieść się do niej. Wyznaczając sobie podstawę źródłową, autor uwzględnił rody, które utrzymały status magnacki w ciągu XVIII w. i po których zachowały się w miarę kompletne archiwa. Dotyczy to Branickich h. Gryf, Chodkiewiczów, Czartoryskich, Lubomirskch, Potockich, Rzewuskich, Sieniawskich, Sanguszków, Tarnowskich i Zamoyskich.

Hubert Wolf, Archiwa Watykanu a III Rzesza, thum. J. Wolska-Stefanowicz, Warszawa 2010, wyd. Bellona, ss. 342

Książka mogła powstać, gdy w Tajnym Archiwum Watykańskim udostępniono materiały pontyfikatu Piusa XI (1922-1939). Samego archiwum dotyczy jeden podrozdział (s. 20-28), w którym autor w barwny sposób roztacza wizję normalnego archiwum w opozycji do demonicznego obrazu Dana Browna. Reszta książki to opowieść o stosunku papiestwa do Żydów, antysemityzmu, prześladowań Żydów, Trzeciej Rzeszy, nazizmu. Ciekawe, z jakiego powodu książkę pozbawiono oryginalnego tytułu brzmiącego „Papst und Teufel” („Papież i diabeł”), uznając, że właściwym tytułem polskiego wydania będzie jedynie podtytuł niemieckiego oryginału („Die Archive des Vatikan und das Dritte Reich")?

Krzysztof Woś, Kancelaria Sejmu. Zadania, struktura, funkcjonowanie, Warszawa 2010, Wydawnictwo Sejmowe, ss. 184

Tytuł mówi sam za siebie z jednym uzupełnieniem, że książeczka zawiera także rys historyczny kancelarii sejmowej od 1918 r.. Nieco miejsca poświęcono Archiwum Sejmowemu (s. 123). Jest to zdecydowanie za mało, ale skoro archiwum ukrywa się w strukturze Biblioteki Sejmowej...

\section{INNE}

Narodowe Archiwum Cyfrowe. Wizja, projekt, ludzie, red. P. Dudek, A. Kowalska, Warszawa 2010, wyd. Narodowe Archiwum Cyfrowe, ss. 180, ilustr.

Narodowe Archiwum Cyfrowe z całą pewnością przoduje w polskim świecie archiwalnym na polu autopromocji. Niektóre publikacje bywają bardzo awangardowe. Ta jest bardziej tradycyjna w wersji treściowej, choć forma wykonania jest niewątpliwie atrakcyjna - to znaczy, że przyciąga uwagę. Znaj- 
dujemy w niej podstawowe informacje o NAC: o jego zadaniach i działaniach, strukturze, zasobie. Nowatorskim pomysłem, całkiem udanym, jest zaprezentowanie archiwum przez wywiady z jego pracownikami. Przyszłość pokaże, czy prezentowane dzieło stanie się wzorcem dla przedsięwzięć promocyjnych innych archiwów, ale nam wydaje się, że tak stać się powinno. Programowy jest zamieszczony w tomie artykuł Nikodema Bończy Tomaszewskiego o podstawowych problemach archiwistyki cyfrowej (po polsku i angielsku). Czy taka archiwistyka istnieje lub o istnienie jej warto zabiegać, to już temat do dyskusji w innym miejscu.

Raport z dziatalności Naczelnej Dyrekcji Archiwów Państwowych i archiwów państwowych za lata 2008-2009. Head Office for State Archives and state archives report for 2008-2009, red. B. Berska, Warszawa 2010, wyd. Naczelna Dyrekcja Archiwów Państwowych, ss. 153, ilustr.

Raport z działalności administracji archiwalnej, przygotowany w przystępnej formie z myślą o szerokim kręgu odbiorców. Omówiono w nim wszystkie aspekty pracy archiwów państwowych w Polsce, zamieszczono obszerne kalendaria wydarzeń, w których uczestniczyły archiwa w latach 2008 i 2009, podano podstawowe informacje adresowe. Wydawnictwo dwujęzyczne. Pierwsze takie wyjście archiwów państwowych ku ludziom. Urzędowego sprawozdania nie byliby w stanie czytać, trzeba więc przemówić do nich językiem zrozumiałym, unikając terminologii fachowej. Zamiast archiwaliów - świadectwa przeszłości. W miejsce narodowego zasobu archiwalnego - dokumentalna spuścizna polskiego państwa i społeczeństwa. Wykonany na Uniwersytecie Mikołaja Kopernika w Toruniu test wykazał, że osoby nieznające archiwistyki lepiej czy precyzyjniej rozumieją poczciwe archiwalia, materiały archiwalne, zasób archiwalny niż świadectwo przeszłości czy spuściznę dokumentalną. Język fachowy okazał się bliższy społecznemu odczuciu. Książka zresztą wcale nie jest konsekwentna, przeplata się w niej bowiem język nowy ze starym, zależy, kto pisze rozdział. W sumie otrzymaliśmy owoc próby potrzebnej, ale nieudanej. No i mnóstwo pięknych ilustracji, tyle że nigdzie nieopisanych. Gdyby była to książka skierowana do fachowców, to rzeczywiście każdy rozpoznałby pieczęć Kazimierza Wielkiego (s. 19). Co jednak z myślącymi i ciekawymi świata laikami?

oprac. Waldemar Chorażyczewski, Robert Degen, Agnieszka Rosa, Krzysztof Syta (Uniwersytet Mikołaja Kopernika w Toruniu) 